2014

\title{
Failure to Report: The Manifestly Unconstitutional Nature of the Human Smugglers Act
}

Jennifer Bond

Follow this and additional works at: http://digitalcommons.osgoode.yorku.ca/olsrps

\section{Recommended Citation}

Bond, Jennifer, "Failure to Report: The Manifestly Unconstitutional Nature of the Human Smugglers Act" (2014). Osgoode Legal Studies Research Paper Series. 77.

http:// digitalcommons.osgoode.yorku.ca/olsrps/77 


\section{OSGOODE}

OSGOODE HALL LAW SCHOOL

YOR K U N I VERSITY

\section{OSGOODE HALL LAW SCHOOL}

LEGAL STUDIES RESEARCH PAPER SERIES

Research Paper No. 1/2014

Vol. 10, No. 3 (2014)

Failure to Report: The Manifestly Unconstitutional Nature of the Human Smugglers Act

Forthcoming in Osgoode Hall Law Journal, Vol. 51, No. 2 (2014)

Jennifer Bond

Editors:

Peer Zumbansen (Osgoode Hall Law School, Toronto; Canada Research Chair in Transnational Economic Governance and Legal Theory - Editor in Chief)

Stephen Ji (Osgoode Hall Law School, Toronto - Production Editor)

Comparative Research in Law \& Political Economy 
Osgoode Legal Studies Research Paper No. 1/2014

Vol. 10, No. 3 (2014)

\title{
Failure to Report: The Manifestly Unconstitutional Nature of the Human Smugglers Act
}

Forthcoming in Osgoode Hall Law Journal, Vol. 51, No. 2 (2014)

Jennifer Bond

\begin{abstract}
:
This paper uses the Human Smugglers Act as a case study with which to explore what can happen when a Canadian government tables legislation that is highly controversial not only for reasons of ideology or policy, but also because it is almost certainly in violation of the Charter. The conclusion is twofold: first, that a requirement originally meant to increase government accountability in the face of Canada's human rights instruments is failing; and second, that this same requirement is now providing "political cover" in situations where the government seeks to deflect legitimate constitutional critique while simultaneously avoiding substantive engagement. It is argued that the result is an impoverished constitutional dialogue and a misled Canadian public.
\end{abstract}

\section{Keywords:}

Charter, Human Smugglers Act, compliance, manifest unconstitutionality, personalized detention

\section{Author:}

Jennifer Bond

Assistant Professor

Faculty of Law, Common Law Section

University of Ottawa

E: jennifer.bond@uottawa.ca 


\section{Failure to Report: The Manifestly Unconstitutional Nature of the Human Smugglers Act}

Jennifer Bond is an Assistant Professor in the Faculty of Law at the University of Ottawa. Many thanks to Edgar Schmidt, Peter Edelmann, Adam Dodek, Kent Roach, Elizabeth Sanderson, and the OHLJ's anonymous reviewers for their helpful comments. This paper was supported by research funding from the Law Foundation of Ontario and I am grateful for the valuable assistance of Michelle Lutfy, Dan Meester, Michelle Bloodworth, Meghan

Fougere, Brian Kells, and Michele Krech at various stages of the research and writing process.

This article will be published in the next issue of the Osgoode Hall Law Journal (51:2). 


\section{Table of Contents}

I) Charter-vetting and the "inescapable" need to report a lack of compliance.

Origins of the need to report. $\quad 4$

Nature of the vetting-process. $\quad 5$

Assessing the risk of non-compliance. $\quad 6$

$\begin{array}{ll}\text { Debate over the effectiveness of section 4.1. } & 7\end{array}$

II) A case study in manifest unconstitutionality: the politics and content of the Human Smugglers Act.

Key provisions of the Human Smugglers Act.

$\begin{array}{ll}\text { Manifest unconstitutionality. } & 17\end{array}$

1) The constitutional need for a personalized detention trigger. 20

2) The constitutional need for timely review of detention. 21

3) The constitutional need to respect principles of fundamental justice and avoid cruel and unusual treatment.

The inability to justify the prima facie Charter violations.

The political advantages of introducing manifestly unconstitutional legislation. 26

III) The shift from government responsibility to political cover. 


\section{Introduction}

When the Preventing Human Smugglers from Abusing Canada's Immigration System Act [Human Smugglers Act] ${ }^{1}$ was introduced in October 2010, it was more than simply its idiosyncratic title that generated attention. Almost immediately, opposition parties, refugee advocates, legal organizations and academics forcefully criticized the government's proposal. Many declared that the new bill was punitive and regressive, arguing that it contained measures that were not only fundamentally unfair but also in violation of a variety of international instruments. ${ }^{2}$ They further claimed that the proposed law represented an egregious and self-evident contravention of Canada's Charter of Rights and Freedoms (Charter). ${ }^{3}$ The government, meanwhile, maintained that Bill C- 49 was a key component of its strategy for combating fraudulent refugee claims and human smugglinga refrain it repeated in both June 2011 when the Human Smugglers Act was re-introduced to a newly elected House of Commons as Bill C-4, ${ }^{4}$ and March 2012, when the contents of the Human Smugglers Act were rolled into Bill C-31, an omnibus refugee bill. ${ }^{5}$ When asked to respond to allegations that the government was deliberately promoting unconstitutional legislation, senior parliamentarians stated unequivocally that the proposed laws were Charter compliant.

This paper uses introduction of the Human Smugglers Act as a case study with which to explore what can happen when a Canadian government tables legislation that is highly controversial not only for reasons of ideology or policy, but also because it is almost

\footnotetext{
${ }^{1}$ Bill C-49, An Act to amend the Immigration and Refugee Protection Act, the Balanced Refugee Reform Act and the Marine Transportation Security Act, 3rd Sess, 40th Parl, 2010 [Bill C-49].

${ }^{2}$ Including: the Convention relating to the Status of Refugees, 28 July 1951, 189 UNTS 150, Can TS 1969 No 6 [Refugee Convention]; the Convention on the Rights of the Child, 20 November 1989, 1577 UNTS 3, Can TS 1992 No 3; the International Covenant on Civil and Political Rights, 6 December 1966, 99 UNTS 171, Can TS 1976 No 47.

${ }^{3}$ Canadian Charter of Rights and Freedoms, Part I of the Constitution Act, 1982, being Schedule B to the Canada Act 1982 (UK), 1982, c 11 [Charter]. For critiques based on legal grounds, see for example: Canadian Council for Refugees, "Bill C-4: Key concerns" (21 June 2011) online: Canadian Council for Refugees <http://ccrweb.ca>; Canadian Bar Association, "Bill C-49, Preventing Human Smugglers from Abusing Canada's Immigration System Act" (November 2010), online: Canadian Bar Association <http://www.cba.org/cba/submissions/pdf/10-78eng.pdf.

${ }^{4}$ There was a Canadian federal election in May 2011 and as a result, Bill C-49 died on the order paper. The newly formed majority government re-introduced the provisions as Bill C-4 in June 2011: An Act to amend the Immigration and Refugee Protection Act, the Balanced Refugee Reform Act and the Marine Transportation Security Act, 1st Sess, 41st Parl, 2011 [Bill C-4]. The text of Bill C-49 and C-4 are essentially identical - with only 2 small differences between them. Both of these are insignificant for the purposes of this paper.

${ }^{5}$ The Human Smugglers Act was incorporated into Bill C-31, An Act to amend the Immigration and Refugee Protection Act, the Balanced Refugee Reform Act, the Marine Transportation Security Act and the Department of Citizenship and Immigration Act, 1st Sess, 41st Parl, 2012 [Bill C-31]. A note about terminology: since my focus is exclusively on the portions of Bill C-31 that were previously contained in the Human Smugglers Act, I will continue to use that title to refer to the relevant provisions. In addition, Bill C-31 is now in force as Protecting Canada's Immigration System Act, SC 2012 c 17. As this paper addresses the review requirements for bills, I will continue to refer to the Act as Bill C-31.
} 
certainly in violation of the Charter. My ultimate conclusion is twofold: first, that a requirement originally meant to increase government accountability in the face of Canada's human rights instruments is failing; and second, that this same requirement is now providing "political cover" in situations where the government seeks to deflect legitimate constitutional critique while simultaneously avoiding substantive engagement. The result, I argue, is a democratic deficit comprised of an impoverished constitutional dialogue and a misled Canadian public.

The discussion proceeds in three sections: Part I describes the government's duty to vet new legislation for inconsistencies with certain human rights commitments, and explains the threshold that has been created for determining when a report on Charter compliance must be issued to the House of Commons. Part II identifies key components of the Human Smugglers Act, and demonstrates that this bill contains blatant constitutional deficiencies that ought to have triggered a report of non-compliance in accordance with the standard described in Part I. That it did not suggests that the reporting requirement is failing as an accountability mechanism. Part III identifies the ways the government is using its legal duty to vet for Charter compliance to evade meaningful constitutional inquiry. Here it is argued that the reporting requirement may in fact be contributing to the erosion of substantive public debate on the constitutional status of new legislation, thereby creating a significant democratic deficit. The final section, Part IV, concludes that the Human Smugglers Act is not an isolated example, and calls for Canada's reporting requirement to be re-visited.

\section{I) CHARTER-VETTING AND THE “INESCAPABLE” NEED TO REPORT A LACK OF COMPLIANCE.}

Section 4.1 of the Department of Justice Act mandates that every government bill be reviewed by the Minister of Justice in order to ascertain "whether any of the provisions thereof are inconsistent with the purposes and provisions of the Canadian Charter of Rights and Freedoms." 6 The minister is also required to report any inconsistencies to the House of Commons. ${ }^{7}$ Regulations corresponding to the provision specify that every government bill that is not the subject of a report must be filed with a certificate acknowledging that the section 4.1 vetting process has occurred. ${ }^{8}$ The Human Smugglers Act is no exception, and

\footnotetext{
${ }^{6}$ Department of Justice Act, RSC 1985, c J-2, s 4.1.

${ }^{7}$ Ibid.

${ }^{8}$ Section 3 of the Canadian Charter of Rights and Freedoms Examination Regulations reads as follows: "In the case of every Bill introduced in or presented to the House of Commons by a Minister of the Crown, the Minister shall, forthwith on receipt of two copies of the Bill from the Clerk of the House of Commons, $(a)$ examine the Bill in order to determine whether any of the provisions thereof are inconsistent with the purposes and provisions of the Canadian Charter of Rights and Freedoms, and $(b)$ cause to be affixed to each of the copies thereof so received
} 
both the Clerk of the House of Commons and the Clerk of the Privy Council have certified copies of Bills C-49, 4, and 31 bearing the following text: "Examined as required by the Canadian Bill of Rights and the Department of Justice Act." The stamp is signed on behalf of the Deputy Minister of Justice. ${ }^{9}$

The following paragraphs briefly explore the section 4.1 reporting requirement. Although this section does not purport to be a comprehensive study, it does provide important context for the discussion in the remainder of this paper.

Origins of the need to report.

Section 4.1 was added to the Department of Justice Act in 1985 as part of series of statutory amendments relating to the introduction of the Charter. ${ }^{10}$ The provision mirrors section 3 of the Canadian Bill of Rights, which requires a similar examination to ensure compliance with the provisions of that instrument. ${ }^{11} \mathrm{~A}$ brief look at the history of section 3 sheds some light on the purpose of these requirements. The Special Committee on Human Rights and Fundamental Freedoms added the reporting requirement to the Bill of Rights after noting that as first drafted, the duty to examine proposed legislation to ensure consistency with the new rights framework was not accompanied by any "concurrent obligation [on the Minister responsible for the examination] to bring his views by way of report before the House of Commons."12

Minister of Justice Edmund Davie Fulton stated that he fully supported a statutorily imposed "specific obligation of reporting," since he viewed this as an "inescapable and necessary implication" of the requirement to examine bills for compliance. ${ }^{13}$ Opposition members of the committee also supported the amendment, finding that the guarantee of reports was a "welcome advance" in the effort to ensure the protection of human rights. ${ }^{14}$ The House of Commons agreed, and the amended section was accepted and introduced with the remainder of the Bill of Rights in 1960.

\footnotetext{
from the Clerk of the House of Commons a certificate, in a form approved by the Minister and signed by the Deputy Minister of Justice, stating that the Bill has been examined as required by section 4.1 of the Department of Justice Act, and one each of the copies thereof so certified shall thereupon be transmitted to the Clerk of the House of Commons and the Clerk of the Privy Council." SOR/85-781, s 3.

${ }^{9}$ Certified copies of Bills C-4, 49, and 31 were obtained by the author through an Access to Information Request. Bill C-49 was certified on 5 November 2010; Bill C-4 was certified on 23 June 2011; and Bill C-31 was certified on 28 February 2012.

${ }^{10}$ Sections 4.1(1) and (2) were added to the Department of Justice Act as part of a bill which aimed to ensure that all Canadian legislation respected the Charter's guarantees. See: Statute Law (Canadian Charter of Rights and Freedoms) Amendment Act, RSC 1985, c 31 (1st Supp), s 93.

${ }^{11}$ Canadian Bill of Rights, SC 1960, c 44, s 3.

${ }^{12}$ House of Commons Debates, 24th Parl, 3rd Sess, Vol VII (1 August 1960) at 7373 (Edmund Davie Fulton).

${ }^{13}$ Ibid.

${ }^{14}$ House of Commons Debates, 24th Parl, 3rd Sess, Vol VII (3 August 1960) at 7494 (Hon Paul Martin).
} 
Despite these initial impressions that the reporting requirement in section 3 was an "inescapable" accountability mechanism, only one report of potential non-compliance with the Bill of Rights has ever been presented to the House of Commons. This occurred in 1975 and related to a Senate amendment to a government bill amending the Feeds Act. ${ }^{15}$ Further, there has never been a report under section 4.1 of the Department of Justice Act. ${ }^{16}$ This means that while over thirty years' worth of government bills have been scrutinized for constitutional compliance, not one has been found to be inconsistent with the Charter through this vetting process. ${ }^{17}$

Nature of the vetting-process.

Although all government-proposed legislation must be vetted for inconsistency with the Charter, ordinary Canadians are unable to access the resulting legal analysis. Neither are most Members of Parliament (MPs). In fact, Canadians outside of those who are high ranking government officials (or who occupy certain bureaucratic posts) are prevented from both seeing the Department of Justice's substantive legal opinions and obtaining details about the process and standards that are applied in order to meet the section 4.1 requirements. Both are said to be protected by solicitor-client and cabinet privilege and are so shrouded in secrecy that they are also explicitly exempted from the scope of the Access to Information Act and the Canada Evidence Act. ${ }^{18}$

Despite the closed nature of the section 4.1 process, some insights into the operationalization of the vetting and reporting requirements can be gleaned through public statements by current and former bureaucrats. In 1977, a former Deputy Minister of Justice

\footnotetext{
${ }^{15}$ See Elmer Driedger, “The Meaning and Effect of the Canadian Bill of Rights: A Draftsman's Viewpoint" (1977) 9 Ottawa L Rev 303 at 306 . The report resulted from a government determination that the changes proposed by the Senate were inconsistent with the Bill of Rights because they conflicted with the presumption of innocence.

${ }^{16}$ Janet L Hiebert, "Rights-Vetting in New Zealand and Canada: Similar Idea, Different Outcomes" (2005) 3 New Zealand Journal of Public and International Law 63 at 65 [Hiebert, "Rights-Vetting"]; Grant Huscroft, "Reconciling Duty and Discretion: The Attorney in the Charter Era" (2009) 34 QLJ 773 at note 57 [Huscroft, "Reconciling Duty"].

${ }^{17}$ In contrast, New Zealand's reporting requirement, which forms part of its Bill of Rights Act (1990), has produced 59 reports, including 28 relating to government bills (Ministry of Justice, "Section 7 reports," online: <http://www.justice.govt.nz/policy/constitutional-law-and-human-rights/human-rights/domestic-human-rightsprotection/about-the-new-zealand-bill-of-rights-act/advising-the-attorney-general/section-7-reports-publishedbefore-august-2002/section-7-reports-published-before-august-2002>). It should be noted that New Zealand's reporting requirement is the main means by which legislation can be evaluated for compliance with the Bill of Rights, as this document does not have supremacy over other acts like the Charter does in Canada.

${ }^{18}$ Access to Information Act, RSC 1985, c A-1, s 69(1)(f)-(g); Canada Evidence Act, RSC 1985, c C-5, s 39. Certified copies of bills are however, available under the Access to Information Act and copies were obtained by the author using this means, see note 9 .
} 
and Deputy Attorney General of Canada described an iterative legislative process which included multiple opportunities for public servants to alert the Minister of Justice and Cabinet of any inconsistencies between proposed legislation and the Bill of Rights. ${ }^{19}$ An Associate Deputy Minister (Public Law) has since confirmed that this consultative structure continued after introduction of the Charter. Mary Dawson's account of the legislative process emphasizes early and frequent involvement by Charter experts housed in a specially created Human Rights Law Section of the Department of Justice. ${ }^{20}$ The ultimate conclusion of both commentators is that because the drafting of new legislation provides ample opportunity for correction, governments are very unlikely to introduce a bill that obviously conflicts with one of Canada's core human rights instruments. ${ }^{21}$

These accounts have been enhanced by academic work on the subject: both James Kelly and Janet Hiebert have published details about implementation of the reporting requirement obtained in part through anonymous interviews with former and current lawyers from the Department of Justice. ${ }^{22}$ Both confirm the important and ongoing role of lawyers in the Human Rights Law Section throughout the drafting process.

Assessing the risk of non-compliance.

Insiders are candid about the unique challenges facing lawyers who must determine whether proposed legislation is non-compliant, particularly with respect to the justification analysis required under section 1 of the Charter. ${ }^{23}$ Mary Dawson comments that it is frequently difficult to quantify the "degree of risk" that would compel a finding of noncompliance, noting that often the most difficult part of the process is characterizing the relevant Charter issues. ${ }^{24}$ Hiebert expands further on the nature of this risk assessment: Justice lawyers have adopted an approach for reviewing bills based on a riskassessment of the degree of difficulty in justifying legislation under the Charter. Risk-assessments are undertaken on a continuum from minimal, significant, substantial, and serious to unacceptable, the latter category representing a near-certainty that courts will invalidate the legislative action.

\footnotetext{
${ }^{19}$ Driedger, supra note 15 at $310-312$.

${ }^{20}$ Mary Dawson, "The Impact of the Charter on the Public Policy Process and the Department of Justice" (1992) 30 Osgoode Hall LJ 595 at 597-599.

${ }^{21}$ Driedger states that "the chances that a statute patently in conflict with the Bill of Rights could be enacted are virtually non-existent." Driedger, supra note 15 at 311. Dawson reaches a similar conclusion, stating that the "legal adviser has a role in helping the [government] client understand the requirements of the Charter as it applies to a particular case" and noting that "[c]learly the Charter does foreclose certain options to governments." Ibid at 599. ${ }^{22}$ James Kelly, "Bureaucratic activism and the Charter of Rights and Freedoms: the Department of Justice and its entry into the centre of government" (1999) 42:4 Can Pub Adm 476; Janet Hiebert, Charter conflicts: what is Parliament's role? (Montreal: McGill-Queen's University Press, 2002) at xii [Hiebert, "Charter conflicts"].

${ }^{23}$ Dawson, supra note 20 at 598, 599. For more on section 1 analysis under the Canadian Charter, see "The inability to justify the prima facie Charter violations", below.

${ }^{24}$ Ibid at 598.
} 


\begin{abstract}
At times, Justice officials have been asked to put their assessment into numerical terms: evaluating whether legislation has a 60 per cent chance of surviving as opposed to a lesser chance, or indicating whether the degree of risk likes on a scale of 1-10...while it can be difficult to distinguish between significant, substantial or serious risks assessments continue to be framed qualitatively. ${ }^{25}$
\end{abstract}

Hiebert also explains that the ultimate threshold for determining whether a bill triggers a report on the basis of Charter inconsistency is "whether or not a credible Charter argument can be made." 26 It is interesting to note that this standard of "any credible argument" appears on its face to be different than the threshold described by Dawson, who refers to a search for "good arguments."27

In 2007, a senior government lawyer provided a more detailed description of the current threshold for establishing the existence of a Charter inconsistency. Testifying before a Legislative Committee considering a criminal law bill, ${ }^{28}$ Stanley Cohen, Senior General Counsel with the Department of Justice's Human Rights Law Section, was unusually candid about the process for vetting bills for inconsistency with the Charter. According to Cohen, a bill is deemed inconsistent with the Charter, and thus in need of a section 4.1 report, if it is assessed as being "manifestly unconstitutional and could not be defended by credible arguments before a court." 29 Cohen explicitly distinguished this threshold from one based on inquiry into whether any "credible argument" for inconsistency can be made. ${ }^{30}$ Debate over the effectiveness of section 4.1.

The foregoing reveals four important features of the section 4.1 reporting requirement. First, it is clear from available accounts that the Department of Justice is involved in

\footnotetext{
${ }^{25}$ Hiebert, "Charter conflicts", supra note 22 at 8.

${ }^{26}$ Ibid at 10.

${ }^{27}$ Dawson, supra note 20 at 598.

${ }^{28}$ The bill under consideration was Bill C-2, The Tackling Violent Crime Act, 2nd Sess, 39th Parl, 2007.

${ }^{29}$ Legislative Committee on Bill C-2, 39th Parl, 2nd Sess (15 November 2007) at 1030-1035. Note that there is some ambiguity about whether Cohen is describing two distinct steps - that both a finding of manifest unconstitutionality and a finding of no credible defense is needed to trigger a report- or whether the latter is simply providing content for the threshold established by the former term. My reading of the entirety of Cohen's testimony suggests that one inquiry is performed, and that a bill will be deemed manifestly unconstitutional where it is incapable of credible defense. This interpretation is supported by the fact that it is difficult to imagine a "manifestly" or "obviously" unconstitutional bill that is nonetheless legally defensible. In the event that my interpretation on this point is incorrect, however, I note that my analysis of the Human Smugglers Act demonstrates that Bills C-49, C-4, and C-31 are both manifestly unconstitutional and incapable of credible defense. ${ }^{30}$ Ibid at 1120 .
} 
providing legal advice about the constitutionality of government-proposed legislation on an on-going and iterative basis. This means there is an opportunity for the government to modify its proposed legislation in response to any constitutional concerns before it is introduced in the House of Commons. Second, since generating this advice requires performing a risk assessment about the likelihood that a particular bill is inconsistent with the Charter, a threshold has been created to determine when the risk is severe enough to warrant a report. Third, how this threshold is defined has changed over time. And fourth, according to the most authoritative public statements on this topic, the current threshold is whether or not the bill is "manifestly unconstitutional." 31

It is important to underscore the two essential interpretive acts inherent in this process. Since section 4.1 provides only the rather vague mandate that a report be provided where a government bill is "inconsistent with the purposes and provisions" of the Charter, it is government lawyers who are charged with both determining the relevant threshold, and subsequently deciding whether the standard they have set has been exceeded in a particular instance. As Adam Dodek rightly observes, the first of these is a "highly discretionary" act of legal interpretation, which will have a significant impact on the number of section 4.1 reports that are eventually made. ${ }^{32}$

The second interpretive act is that of determining whether a particular piece of pending government legislation surpasses whatever threshold has been established such that it ought to be deemed "inconsistent with the Charter" and thus trigger a report. It is perhaps self-evident that since the whole purpose of this second exercise is to meaningfully distinguish between bills on either side of a line, there must exist, at least at a theoretical level, bills capable of occupying both the "inconsistent" and "not inconsistent" categories. Indeed, it is the ability to segregate into two available classes that gives any threshold meaning. A key question plaguing section 4.1 of the Department of Justice Act is whether the complete absence of reports in Canada indicates that the threshold for Charter compliance has been interpreted in such a way that it is incapable of ever identifying content for the "inconsistent" category. If so, it can be said that the reporting requirement is unable to function as an effective accountability mechanism.

Grant Huscroft is among those who argue that this is not the case. He states that the lack of section 4.1 reports is neither surprising nor troubling, emphasizing that the highly consultative drafting process means that many government bills will be amended in

\footnotetext{
${ }^{31}$ More information about the current threshold has recently become available as a result of a legal challenge launched by a Department of Justice lawyer who alleges ongoing violations of the section 4.1 requirements. More information on the status of this development at the time of writing is provided in "The Shift from Government Responsibility to Political Cover", below.

${ }^{32}$ Adam Dodek, "Lawyering at the Intersection of Public Law and Legal Ethics: Government Lawyers as Custodians of the Rule of Law" (2010) 33 Dal LJ 1.
} 
response to Charter concerns long before they are introduced in the House of Commons. ${ }^{33}$ Under this view, the threshold is adequately performing its distinguishing function and is facilitating not only the identification, but also the correction, of any constitutionally deficient bills. Thus, according to Huscroft, the ongoing lack of section 4.1 reports is not indicative of a failed accountability mechanism, but rather of a process that is preventing blatantly unconstitutional legislation from ever being tabled. It is worth noting that one of the appeals of a functioning "internal correction model"34 of the kind described by Huscroft is that government lawyers are almost certainly more likely to raise constitutional concerns when they can do so in a way that will not lead to embarrassing and potentially costly political consequences for their government clients. A section 4.1 process focused on internal correction thus has the benefit of allowing Department of Justice lawyers to generate meaningful Charter assessments without being preoccupied with the political and institutional implications of doing so. Likewise, the government can consider its responses to these concerns in the absence of public scrutiny and critique, which may encourage more honest and careful deliberation.

Huscroft's defence of the reporting requirement on the basis of internal correction is supplemented by his theory of "underdeterminacy," which emphasizes the fact that the Charter is vague and can be the subject of multiple legitimate interpretations. ${ }^{35}$ In Huscroft's view, this means not only that there can be disagreement about how existing case law applies to proposed legislation, but also that the Attorney General-as an independent interpreter of the Charter-can legitimately disagree with judicial precedent when determining whether a bill requires a report under section 4.1.36 This portion of his analysis explains why constitutionally suspect bills can sometimes be introduced in the House of Commons notwithstanding the rigor imposed by a functioning internal correction model. The underdeterminate nature of the Charter, Huscroft tells us, means that there can be different, but equally legitimate views about when the threshold of inconsistency is passed. As a result, the introduction of controversial bills in the absence of accompanying reports is not a reliable indicator of an ineffective section 4.1 process, and we should continue to have confidence that the most egregious concerns are being identified and corrected before government legislation is brought to the House of Commons.

\footnotetext{
${ }^{33}$ Huscroft, "Reconciling Duty", supra note 16. A similar view has been expressed during conversations between the author and senior lawyers with the Department of Justice.

${ }^{34}$ The term "internal correction model" is my own but I believe it to be an appropriate label for the process Huscroft describes.

${ }^{35}$ Grant A Huscroft “'Thank God We're Here': Judicial Exclusivity in Charter Interpretation and Its Consequences" (2004) 25 SCLR (2d) 241; Huscroft, "Reconciling Duty", supra note 16.

${ }^{36}$ Huscroft, "Reconciling Duty", supra note 16 at 779.
} 
Other commentators are more skeptical that the reporting requirement is living up to its promise of providing accountability under Canada's human rights instruments. James Kelly refers to section 4.1 as a mere "procedural requirement," noting that the absence of reports, even in the face of particularly controversial legislation, demonstrates the "hollowness" of the duty. ${ }^{37}$ Kent Roach echoes this sentiment and emphasizes the need for the provision to meaningfully distinguish between "inconsistent" and "not inconsistent" bills. In his words: "if anything and everything can be credibly defended under the Charter, the reporting requirement should be repealed as a charade." 38 Roach also takes issue with Huscroft's underdeterminacy arguments, stating that "a celebration of indeterminacy may be an appropriate philosophy for some scholars, but it is not an appropriate one for a law officer of the Crown."39 Roach ultimately concludes that the complete absence of reporting under section 4.1 is troubling and that the requirement has effectively "withered on the vine." 40

Huscroft's response to these critiques is significant for our purposes. In an article published in 2009, he clarifies that he does not see the Charter as being so underdeterminate that a report of inconsistency should never be issued, even when the possibility of multiple interpretations is accounted for. ${ }^{41}$ In so doing, he is both acknowledging that the two broad categories of bills relevant to the reporting requirement must be capable of delineationthose that are consistent with the Charter and those that are not-and agreeing with other commentators that section 4.1 must be operationalized in a way that is capable of providing meaningful distinction between these categories. Huscroft's response to his critics also adds an important observation to his theory of underdeterminacy, noting that political considerations offer an additional constraint on the government's ability to introduce legislation that appears on its face to be blatantly inconsistent with Charter precedent:

No Attorney general is likely to adopt an interpretation of the Charter that flouts well-settled precedent. The political constraints on doing so are too great, not only for the Attorney General but also for the government. Governments will have their own reasons for not wanting to introduce a bill that appears to be inconsistent with Charter case law, even assuming that the Attorney General were to approve. They will not want to pick a fight with the courts, given the respective stature of politicians and judges, nor will they want

\footnotetext{
${ }^{37}$ James B Kelly, “Legislative Activism and Parliamentary Bills of Rights: Institutional Lessons for Canada” in James B Kelly \& Christopher P Manfredi, eds, Contested Constitutionalism (Vancouver: UBC Press, 2009) 86 at 93 [Kelly, "Legislative Activism"].

38 Kent Roach, “Not Just the Government's Lawyer: The Attorney General as Defender of the Rule of Law" (2006) 31 QLJ 598 at 625 [Roach, "Not Just the Government's Lawyer"].

39 Ibid.

${ }^{40}$ Ibid at 626.

${ }^{41}$ Huscroft, "Reconciling Duty", supra note 16 at 792, in response to Roach, "Not Just the Government's Lawyer", supra note 38 at 625 .
} 
to waste political capital on legislation that is obviously vulnerable to judicial invalidation... ${ }^{42}$

Section 4.1 is thus presented as operating in tandem with political pressures that favour Charter compliance. It is suggested that together these two mechanisms provide suitable accountability measures by ensuring that blatantly unconstitutional legislation is rarely introduced. When it is, explicit notice must be given through a report to the House of Commons.

An important footnote accompanies Huscroft's assertion on this point: at note 13 he acknowledges that in some situations governments may perceive that the political benefits of introducing particular legislation outweigh the political downsides of having the measure eventually declared unconstitutional. Further, in these situations the government is rewarded not only for introducing the controversial measures, but also for later criticizing the courts for striking down popular legislation. ${ }^{43}$ Huscroft does not elaborate on how his observation in footnote 13 intersects with the reporting requirement, but I would argue that these are precisely the types of situations in which we would expect section 4.1 of the Department of Justice Act to yield a report: when the government decides that it is "indifferent to the constitutional fate of its legislation" 44 it should nonetheless be mandated, by virtue of the reporting requirement, to make the House of Commons and the Canadian public aware of its decision to proceed despite significant Charter risks. This does not prevent such legislation from becoming law, of course, but it does require public admission by the government that it is pursuing a legislative agenda that appears to be inconsistent with the instruments designed to protect fundamental rights.

Elmer Driedger reached a similar conclusion in 1977, stating that "the chances that a statute patently in conflict with the Bill of Rights could be enacted are virtually nonexistent, unless that were deliberate government policy, in which case the declaration would go in and the Government would have to face the music in the House of Commons." 45 Driedger also emphasizes the important democratic role the requirement plays, noting that the accountability scheme introduced in the Bill of Rights ensures that where the government knowingly tables legislation that does not comply with its guarantees " $[\mathrm{t}] \mathrm{he}$ issue would then be squarely before Parliament and, if the bill became law, would ultimately be adjudged by the electorate." 46

\footnotetext{
${ }^{42}$ Huscroft, "Reconciling Duty", supra note 16 at 780.

${ }^{43}$ Ibid at note 13 .

44 Ibid.

${ }^{45}$ Driedger, supra note 15 at 311 [emphasis added].

${ }^{46}$ Ibid.
} 
In my view, it is these situations that present the true litmus test for the effectiveness of section 4.1. It is conceivable, perhaps even desirable, that the vetting and reporting functions constitute part of an effective internal correction process, and that the lack of reports in Canada is, as Huscroft suggests, indicative of its success as an accountability mechanism because the majority of major Charter deficiencies are corrected before bills are even introduced. It is also likely that in some situations there will be legitimate disagreement about whether a particular bill is inconsistent with the Charter. As such, critique of proposed legislation on Charter grounds, or even subsequent invalidation by a court, is also not conclusive evidence of a failed accountability mechanism, since this could merely reflect the difficult interpretative tasks involved in assessing Charter compliance. Further, while I am more skeptical about the legitimacy of a failure to provide a section 4.1 report on the basis that judicial precedent is deemed by another interpreter as "wrong," I am willing to accept that disagreement on the margins of the case law may be acceptable in some circumstances. Thus, neither the lack of reports nor the presence of genuine and legitimate debate about the Charter compliance of particular bills is alone sufficient to demonstrate that Canada's reporting requirement is ineffective. However, when a government chooses to introduce legislation that is obviously inconsistent with clear and recent judicial precedent from this country's highest court because it deems there is political advantage to doing so, a meaningful application of section 4.1 ought to find inconsistency and trigger a report. If it does not, one must conclude that the mechanism designed to ensure public accountability has failed.

In the section that follows, I will argue that this is exactly what occurred when the government introduced The Human Smugglers Act.

\section{II) A CASE STUDY IN MANIFEST UNCONSTITUTIONALITY: THE POLITICS AND CONTENT OF THE HUMAN SMUGGLERS ACT.}

The Human Smugglers Act introduces amendments to the Immigration and Refugee Protection Act [IRPA],47 the Balanced Refugee Reform Act [BRRA],48 and the Marine Transportation Security Act. ${ }^{49}$ Collectively, these changes give the government power to designate certain groups of arrivals to Canada as "irregular." 50 The result of this designation is a modified process for those wishing to claim asylum, as well as modified rights once status as a legal refugee has been obtained.

\footnotetext{
47 Immigration and Refugee Protection Act, SC 2001, c 27.

${ }^{48}$ Balanced Refugee Reform Act, SC 2010, c 8.

${ }^{49}$ Marine Transportation Security Act, SC 1994, c 40.

${ }^{50}$ Bill C-49, supra note 1 at cl 4 (which will introduce IRPA 20.1). See also Bill C-4, supra note 4 at cl 5; Bill C-31, supra note 5 at $\mathrm{cl} 10$.
} 
The context in which the Human Smugglers Act was introduced is significant. In August 2010, the MV Sun Sea arrived in Canadian waters carrying 492 Sri Lankan Tamils. All of the men, women, and children onboard the ship claimed that they were fleeing persecution and thus entitled to protection as refugees. The government greeted the boat with military vessels and immediately detained all of the claimants. ${ }^{51}$ It also publicly declared that the Sun Sea posed a threat to both Canada's national security and the integrity of our immigration system as a result of what it viewed as blatant "queue jumping" by those on board, some of whom could have links to a terrorist organization. ${ }^{52}$ Bill C-49 was introduced two months later. At that time, the government portrayed it as a critical part of its "crack down" on human smugglers. Although the bill died on the order paper when a federal election was called in March 2011, the Human Smugglers Act was reintroduced as Bill C-4 by a strengthened majority government in June 2011. Nine months later, all of its provisions were rolled into Bill C-31, an omnibus refugee bill that introduces sweeping changes to the process and substance of Canada's asylum system. ${ }^{53}$

This section identifies key provisions of the Human Smugglers Act and argues that Bills C49,4 , and 31 were manifestly unconstitutional at the time they were introduced by the government. As a result, each ought to have triggered a section 4.1 report to the House of Commons. It is significant that none of them did. Further, the political environment in which this legislation was introduced supports a conclusion that the government likely saw strategic advantage in proceeding with the bills, notwithstanding the constitutional violations they contained. The absence of a report in these kinds of circumstances is particularly troubling and highlights the abject failure of section 4.1 to serve as an effective accountability mechanism, even when it is most needed.

\footnotetext{
${ }^{51}$ Detention of foreign nationals is governed by sections $54-61$ of the un-modified IRPA. Commentators criticized the Sun Sea detentions on the basis that they were longer than necessary and thus violated fundamental human rights. See: Canadian Council for Refugees, Media Release, "Rights advocates decry detention of refugee claimants from MV Sun Sea" (10 February 2011), online: CCR <http://ccrweb.ca >.

${ }^{52}$ See e.g. remarks of Vic Toews, "Human Smuggling and the Abuse of Canada's Refugee System" (21 October 2010), online: Public Safety Canada <http://www.publicsafety.gc.ca>. Canada put the Liberation Tigers of Tamil Eelam (LTTE) on its list of terrorist organizations in 2006: see Public Safety, "Currently Listed Entities", online: Public Safety Canada <http://www.publicsafety.gc.ca>.

${ }^{53}$ This paper focuses only on the portions of Bill C-31 that were previously contained in Bills C-49 and C-4. For government backgrounders on a variety of key changes proposed in Bill C-31, including many not discussed here, see: Citizenship and Immigration Canada, News Release, "Harper Government Introduces the Protecting Canada's Immigration System Act"(16 February 2012), online: Citizenship and Immigration Canada <http://www.cic.gc.ca>. For a commentary of some of these changes see: Canadian Association of Refugee Lawyers, "CARL Responds to New Refugee Legislation"(16 February 2012), online: CARL <http://refugeelawyersgroup.ca/billc31>; Canadian Association of Refugee Lawyers, "Bill C-31: The Minister says one thing; his Bill says another" (22 March 2012), online: http://refugeelawyersgroup.ca/theministersays.
} 
Key provisions of the Human Smugglers Act.

Despite its rhetorical title, ${ }^{54}$ a very small minority of the provisions in the Human Smugglers Act deal specifically with those who might be accused of perpetrating human smuggling. ${ }^{55}$ This is likely a result of the fact that severe sanctions were already in place when the Sun Sea's arrival prompted the drafting of Bill C-49: the un-modified IRPA ${ }^{56}$ specifies that those who knowingly assist large groups of individuals to come to Canada without appropriate documentation are liable for a fine of up to $\$ 1,000,000$ and life imprisonment. ${ }^{57}$ Also surprising is the fact that the bills-which have been widely promoted by government ministers standing in front of a large and rather ominous-looking photo of the Sun Sea ${ }^{58}$ - do not deal specifically with asylum seekers traveling by boat, or otherwise make distinctions based on mode of arrival. Instead, the proposed legislation gives the Minister very broad discretion to declare a group 59 of arrivals "irregular" regardless of their mode of entry into Canada. ${ }^{60}$ The bills permit such a designation whenever the Minister a) is of the opinion that investigating or establishing the identity of any member(s) of the group cannot be conducted in a timely fashion; or b) has reasonable grounds to suspect that an individual has profited from assisting the group to reach Canada without complying with "normal" processes, including acquiring necessary visas and other

\footnotetext{
${ }^{54}$ For some interesting reflections on the increasingly rhetorical nature of bill titles generally, see: Bruce Cheadle, "Motherhood titles for government bills used to sell legislation to public", The Canadian Press (16 February 2012) online: Global TV BC <http://www.globaltvbc.com>.

${ }^{55}$ Provisions which deal with human smuggling directly include: Bill C-31, supra note 5 at cls 41-42, 70-77.

${ }^{56}$ IRPA, supra note 47. The IRPA is the framework legislation governing Canada's immigration and refugee processes and the majority of major changes proposed in the Human Smugglers Act are realized through amendment to its provisions.

${ }^{57} \mathrm{Ibid}$ at s 117. Despite the availability of these severe sanctions, s 117 has rarely been used, and since 2002 there have been a limited number of criminal cases under the section, see: $R v$ Damani, [2003] OJ No 5493; $R v$ Bello, [2004] OJ No 5312; R c Bejashvili, 2007 QCCQ 15809; R c Savaresse-Belapatino, 2007 QCCQ 1251; R v Ng, 2008 BCCA 535; $R$ v Alzehrani, [2009] OJ No 5797; $R v$ Toor , [2009] OJ No 5982; $R v$ Singh-Murray, 2011 NBPC 34; $R v$ Prone, 2012 BCPC 219. In $R v$ Appulonappa, 2013 BCSC 31, four individuals accused under s. 117 of the un-modified IRPA successfully challenged the constitutionality of the provision (as worded prior to Bill C-31's entrance into force), claiming that it inadvertently captured the actions of humanitarian workers and close family members, and therefore was inconsistent with principles of fundamental justice contrary to s. 7 of the Charter. The BC Supreme Court agreed and held that s. 117(1) was overbroad and therefore of no force and effect. The decision is currently under appeal. The Human Smugglers Act modifies s 117 by introducing new mandatory minimum sentences and creating culpability in situations of recklessness.

${ }^{58}$ The standard image used to promote the bill is available at: Public Safety Canada, "Human Smuggling" (5 July 2012), online: Public Safety Canada <http://www.publicsafety.gc.ca>.

${ }^{59}$ It is significant to note that the bill does not define the term "group", meaning that any claimant who does not arrive alone may be susceptible to being declared a designated foreign national. Ambiguity regarding this term further expands the Minister's discretionary power to designate.

${ }^{60}$ Bill C-31, supra note 5 at $\mathrm{cl} 10$ (designation provision). See also Bill C-4, supra note 4 at cl 5; Bill C-49, supra note 1 at $\mathrm{cl} 4$.
} 
documentation. ${ }^{61}$ The designation criteria are inherently vague, and the minister is thus left with tremendous discretion to determine which groups will be designated.

Individuals falling within a group of irregular arrivals are deemed to be "designated foreign nationals" and the majority of the Human Smugglers Act introduces amendments that alter the asylum claims process for those who have been so labeled. Perhaps most significantly, the act creates a mandatory detention scheme for all designated foreign nationals. Although there is slight variation in the detail between versions of the Human Smugglers $A c t$, the foundational elements of the detention scheme were consistent at the time each of Bills C-4, C-49, and C-31 were tabled in the House of Commons.

Bills C-49 and C-4 introduced a mandatory detention scheme that applied to all designated foreign nationals. This regime required a minimum detention period of twelve months, and detention could not be reviewed prior to expiration of this period. Subsequent detention review was only permitted once every six months. ${ }^{62}$ Bill C-31 altered this scheme slightly by specifying that only designated foreign nationals aged sixteen and over would be subject to mandatory detention. ${ }^{63}$ Although the bill is silent on what will happen to those under the age of sixteen, statements by the government suggest an intent that children whose parents are in detention would either be detained with them or taken into custody by the relevant provincial child welfare agency. ${ }^{64}$ All other aspects of the regime remained unchanged until the Minister of Citizenship, Immigration and Multiculturalism, Jason Kenney, announced further modification several months after the Human Smugglers Act had been re-introduced as part of Bill C-31, and following two weeks of expert testimony on a variety of aspects of the omnibus bill. The changes allow designated foreign nationals access to detention review within 14 days, and to subsequent reviews every six months. Further, they granted the Minister of Public Safety the ability to order the release of designated foreign nationals at any time, although only on the Minister's own initiative. ${ }^{65}$ It is noteworthy for our purposes that government lawyers were required to assess the constitutionality of each of Bills C-49, C-4, and C-31 before they were introduced in the House of Commons and thus, in the case of C-31, before this final modification.

\footnotetext{
${ }^{61}$ Ibid. See also: Bill C-4, supra note 4 at cl 5; Bill C-31, supra note 5 at cl 36.

62 Bill C-49, supra note 1 at cls 9-11 (amending IRPA ss 55, 56, 57). The only exception is that release can (but not

"must") occur once status is granted. See also Human Smugglers Act, supra note 4 at cls 10-12.

${ }^{63}$ Bill C-31, supra note 5 at cl 23(3).

${ }^{64}$ House of Commons Debates, 41st Parl, 1st Sess, No 97 (15 March 2012) at 1100, 1540, 1605 (Kevin Lamoureux, Hon Vic Toews, Kennedy Stewart, Hon Bal Gosal, Joy Smith, Hon Jason Kenney).

${ }^{65}$ See Citizenship and Immigration Canada, News Release, "Amendments to the Protecting Canada's Immigration System Act" (9 May 2012) online: CIC <http://www.cic.gc.ca>.
} 
In addition to mandatory detention, the Human Smugglers Act also stipulates that a designated foreign national must wait at least five years from the date of a final determination regarding refugee status before applying for permanent residency, ${ }^{66}$ for a temporary resident permit, ${ }^{67}$ or to stay in Canada on humanitarian and compassionate grounds, ${ }^{68}$ and, further, that either permanent residency or a temporary resident permit is required for issuance of a refugee travel document. ${ }^{69}$ Designated individuals are unable to access the Refugee Appeal Division (RAD) ${ }^{70}$ and may be subject to reporting conditions even after refugee status has been granted..$^{71}$ The majority of the Human Smugglers Act is retroactive, in that the designation procedure-and a majority of the consequences of being designated — can be applied to any group that arrived after 31 March $2009 .{ }^{72}$ As a result, passengers of the Sun Sea could be subject to designation once the act came into force. ${ }^{73}$

It is important to note that non-designated asylum seekers may also be detained upon arrival to Canada where there are concerns regarding their identity or their likelihood to miss a necessary appearance, or reasonable grounds to believe that they are a danger to the public or inadmissible for security related reasons. ${ }^{74}$ Unlike under the Human

\footnotetext{
${ }^{66}$ Bill C-49, supra note 1 at $\mathrm{cl} 3$ (amending IRPA s 11). See also Human Smugglers Act, supra note 4 at cl 4; Bill C-31, supra note 5 at $\mathrm{cl} 5$.

${ }^{67}$ Bill C-49, supra note 1 at $\mathrm{Cl} 6$ (amending IRPA s 24). See also Bill C-4, supra note 4 at cl 7; Bill C-31, supra note 5 at cl 12.

${ }^{68}$ Bill C-49, supra note 1 at $\mathrm{cl} 7$ (amending IRPA s 25). See also Bill C-4, supra note 4 at cl 8; Bill C-31, supra note 5 at Cl 13(1).

${ }^{69}$ Bill C-49, supra note 1 at cl 8 (amending IRPA s 31). See also Bill C-4, supra note 4 at cl 9; Bill C-31, supra note 5 at cl 16.

${ }^{70}$ Bill C-49, supra note 1 at $\mathrm{cl} 16$ (amending IRPA s 110). See also Bill C-4, supra note 4 at cl 17; Bill C-31, supra note 5 at $\mathrm{cl} 36$. Although the un-modified IRPA includes a section establishing the Refugee Appeal Division (RAD), this section was never brought into force. The BRRA is intended to actually operationalize the RAD. However, Bill C-31 also restricts the RAD's availability in certain circumstances: in addition to decisions denying status to those deemed to be "designated foreign nationals", the RAD will also be unavailable for decisions: declaring a claim to be withdrawn or abandoned; rejecting a claim on the basis it has no credible basis; rejecting a claim on the basis that it is manifestly unfounded; rejecting a claim made by an individual who, although he or she has travelled through a Safe Third Country, fits within an exception to the rule that generally prohibits claims from such individuals; rejecting a claim by an individual who is a national of a country that the Minister has designated as a Safe Country of Origin; finding that previously granted refugee protection has ceased; or vacating an earlier decision to grant refugee protection.

${ }^{71}$ Bill C-49, supra note 1 at $\mathrm{cl} 15$ (amending IRPA s 98). See also Bill C-4, supra note 4 at cl 16; Bill C-31, supra note 5 at $\mathrm{Cl} 32$.

${ }^{72}$ Bill C-49, supra note 1 at $\mathrm{cl} 33(1)$-(2). Individuals who arrived prior to the coming into force of the amendments and are not in detention on the date they become designated foreign nationals are not subject to the mandatory period of detention (ibid at $\mathrm{cl} 33(3)$ ). See also Bill C-4, supra note 4 at $\mathrm{cl} 34$; Bill C-31, supra note 5 at $\mathrm{cl} 81$.

${ }^{73}$ At the time of writing, nineteen Sun Sea passengers have been ordered deported; seven have been accepted as refugees; and seven have had their claims rejected. See Douglas Quan, "More charges laid in Sun Sea peoplesmuggling operation", Postmedia News (6 June 2012) online: Canada.com <http://www.canada.com>. This means that over 450 Sun Sea passengers could be subjected to retroactive designation under Bill C-31.

${ }^{74}$ IRPA, supra note 47 at ss $54-55$.
} 
Smugglers Act, however, such detentions must be reviewed twice within the first seven days, ${ }^{75}$ and every 30 days thereafter. ${ }^{76}$ Release will be ordered unless specific factors justifying ongoing detention are triggered. ${ }^{77}$ Further, the requirement that five years pass before various applications are made does not apply, travel documents are available to those who have been granted refugee status, and appeals to the RAD will be possible for most claimants as soon as the division is operational. ${ }^{78}$

The result of these provisions is that the Human Smugglers Act creates two very different refugee systems for those seeking protection in Canada: one for individuals who arrive as part of a group that the Minister declares "irregular" and one for other claimants. ${ }^{79}$ The government's justification for this differentiation is that the more punitive system for those arriving in ways it does not like will send "a clear message that the abuse of our immigration system will not be tolerated." 80 Manifest unconstitutionality.

A variety of political, legal, and constitutional allegations have been levied against the Human Smugglers Act. Commentators have attacked the designation process as discriminatory; the retroactivity clause and the lack of appeal mechanism as contrary to principles of fundamental justice; and the five years delay provisions as violations of rights to family life and facilitated integration. ${ }^{81}$ This paper will not grapple with the majority of

${ }^{75}$ One within the first 48 hours: ibid at ss 57(1), (2).

${ }^{76}$ Ibid at s 57(2).

77 These factors are listed in 58 of the IRPA, ibid.

78 Bill C-31 does, however, restrict the availability of the RAD to certain other types of claimants as well. See footnote 70, above.

${ }^{79}$ Bill C-31 also significantly modifies the refugee claims process for individuals arriving from designated countries of origin (DCO). The Minister can designate a country of origin on the basis of a low acceptance rate from claimants originating from that country or its perceived democratic structure, see: Bill C-31, supra note 5 at cl 58 . Arrival from a DCO results in faster processing timelines and an inability to access the RAD, but does not lead to mandatory detention or affect the rights of individuals after they have been declared legitimate refugees (unlike the consequences of being a designated foreign national).

${ }^{80}$ Hon. Jason Kenney, as cited in Alexandra Posadzki, "Government says high number of immigrants will help economic recovery" The Globe and Mail (14 February 2011), online: The Globe and Mail $<$ http://theglobeandmail.com>.

${ }^{81}$ For a summary of some of the arguments relating to the constitutionality of the Human Smugglers Act see e.g.: Canadian Council of Refugees, "Bill C-4: Key concerns" (21 June 2011), online: Canadian Council of Refugees http://ccrweb.ca/en/c4-key-concerns; Canadian Civil Liberties Association, "Bill C-31: An Unjustified Assault on the Rights of People in Danger" (30 April 2012), online: CCLA <http://ccla.org/wordpress/wpcontent/uploads/2012/04/2012-04-30-Submissions-to-Committee-FINAL.pdf>; Canadian Association of Refugee Lawyers, "The Unconstitutionality of Bill C-4, The Preventing Human Smugglers from Abusing Canada's Immigration System Act" (October 2011), online: University of Ottawa Human Rights Research and Education 
these allegations. Rather, I focus exclusively on the bill's detention provisions, and demonstrate that at least some portions of Bills C-49, C-4, and the C-31 run directly contrary to recent and leading constitutional authorities. I therefore conclude that these provisions render the Human Smugglers Act "manifestly unconstitutional," and thus that a section 4.1 report should have accompanied its introduction in the House of Commons all three times it was tabled.

It is important to highlight from the outset that this analysis focuses exclusively on the three primary versions of the Human Smugglers Act that were considered under section 4.1 of the Department of Justice Act. As a result, the following paragraphs account for changes made before Bill C-31 was introduced, but do not assess the constitutionality of the amendments that were made after the bill went to committee. While I do not believe that these amendments render the Human Smugglers Act constitutionally-compliant, it is significant that this more moderate version of the detention scheme was not what was before Department of Justice lawyers prior to the tabling of Bills C-49, C-4, or C-31.

It is also noteworthy that while controversial, 82 detention of asylum seekers who have been neither convicted nor charged with a criminal act occurs with some frequency in Canada and, indeed, in many other countries. ${ }^{83}$ Refugee claimants (and other non-Canadians in Canada) benefit from the Charter's guarantees, ${ }^{84}$ but certain forms of immigration detention are assumed to represent an acceptable balance between the protected liberty interests of the individual, the security interests of the public, and the sovereignty of the state. As a result, such detentions may be Charter compliant where they are non-arbitrary and in conformity with the principles of fundamental justice. ${ }^{85}$

Centre <http://www.cdp-

hrc.uottawa.ca/projects/refugeeforum/projects/documents/TheUnconstitutionalityofBillC4final.pdf>; Canadian Council for Refugees, "Bill C31 - Diminishing Refugee Protection" (April 2012), online: CCR

<http://ccrweb.ca/files/ccrbriefc31.pdf>.

${ }^{82}$ See e.g.: United Nations High Commissioner for Refugees, "UNHCR urges states to avoid detaining asylumseekers" (12 May 2011), online: UNHCR <http://www.unhcr.org>; Michael Flynn, "Immigration Detention and Proportionality: Global Detention Project Working Paper No. 4" (February 2011), online: Global Detention Project <http://www.globaldetentionproject.org/fileadmin/publications/GDP_detention_and_proportionality_workingpap er.pdf>.

${ }^{83}$ For example, Australia, Greece, Israel, Japan, Lebanon, Morocco, South Africa, the United Kingdom, and the United States all have policies for detaining new arrivals under certain (non-criminal) circumstances. For more examples and details according to country, see Global Detention Project, "Country Profiles", online: Global Detention Project <http://www.globaldetentionproject.org/countries.html>.

${ }^{84}$ See Singh v Minister of Employment and Immigration, [1985] 1 SCR 177, 17 DLR (4th) 422.

${ }^{85}$ See Sahin v Canada, [1995] 1 FC 214. Although detention under the IRPA for non-security purposes has not been directly considered by the Supreme Court of Canada, the Court has noted in obiter that the presence of a "comprehensive and expert statutory scheme which provides for review at least as broad as that available by way of habeas corpus" may preclude the need for habeas corpus in certain circumstances: May v Ferndale, [2005] 3 SCR 809 at para 40. 
In 2007, the Supreme Court of Canada considered the constitutionality of one particularly contentious - and widely publicized-form of "immigration detention": the detention of non-Canadians who have been deemed inadmissible to Canada on security grounds but denied access to the evidence used to reach this decision against them. The IRPA provides an entire process for the use of confidential information in proceedings of this nature and further allows for the detention and deportation of affected individuals subsequent to the issuance of a special "security certificate" based on the protected evidence. ${ }^{86}$ In $R v$ Charkaoui, ${ }^{87}$ the Court identified two critical concerns with the security certificate regime. First, it noted that while permanent residents subject to security certificates could be detained under the IRPA, foreign nationals in the same situation had to be detained. ${ }^{88}$ Second, the Court highlighted the requirement that detention of permanent residents be reviewed within 48 hours, while foreign nationals were statutorily barred from even applying for review until 120 days after a judge of the Federal Court determined the reasonableness of the underlying certificate. ${ }^{89}$ The result of these two features of the regime was a bifurcated system in which the procedural protections afforded to certain security certificate detainees were denied to others.

The Supreme Court of Canada ultimately held that detention under the IRPA's security certificate regime violated Charter rights against arbitrary detention and denial of habeas corpus. Further, compliance with the rights not to be subjected to cruel and unusual treatment and deprived of one's liberty except in accordance with the principles of fundamental justice depends on a process that "provides regular opportunities for review of detention" and takes into account a series of relevant factors provided by the Court. ${ }^{90}$

There is no easy way to reconcile the Court's recent holdings in Charkaoui with a view that the detention provisions in Bills C-49, C-4, and C-31 are constitutional. Three particular aspects of the Court's analysis are problematic for the Human Smugglers Act: 1) the need for a personalized detention trigger; 2) the requirement for timely and regular detention review, even in the face of a potential security threat; and 3) the need to respect principles

\footnotetext{
${ }^{86}$ The certificate is issued by the minister and reviewed by a judge who determines whether the issuance was reasonable (IRPA, supra note 47 at ss 70, 80; Charkaoui v Canada (Minister of Citizenship and Immigration), 2007 SCC 9 at para 5, [2007] 1 SCR 350, [Charkaoui]). Charkaoui also dealt with the use of confidential information in the security certificate process, with the court finding that processes preventing the detainee and his or her counsel from accessing the information violated the Charter.

${ }^{87}$ Ibid.

${ }^{88} \mathrm{Ibid}$ at para 6 . The security certificate regime applies to permanent residents and foreign nationals. The IRPA defines the latter as: "a person who is not a Canadian citizen or a permanent resident, and includes a stateless person" (s. 2(1)).

${ }^{89}$ Ibid.

90 lbid at paras 88-127.
} 
of fundamental justice and avoid cruel and unusual punishment. Each of these aspects is discussed in more detail below. This is followed by analysis concluding that there is a lack of legal justification for any of these prima facie violations of the Charter. 1) The constitutional need for a personalized detention trigger.

Despite finding that the IRPA's security certificate regime violated the Charter, the Supreme Court of Canada rejected an argument that the mandatory nature of the detention for foreign nationals was itself sufficient to render the entire process arbitrary, finding instead that the signing of the security certificate constituted a "triggering event" sufficient to legitimize the detention. According to the Court, "the signature of a certificate...is necessarily related to the dangerousness of the individual," and therefore provides a "rational" (rather than arbitrary) foundation for the detention. ${ }^{91}$ The Court explained that it was this personalized triggering event that distinguished detention under the security certificate regime from unconstitutional detention under former Criminal Code provisions that applied to all individuals acquitted from criminal conviction by reason of insanity. ${ }^{92}$ In Charkaoui, the Court emphasized that the latter kind of detention was unconstitutionally arbitrary because not all of the individuals being detained under the impugned provisions were dangerous. ${ }^{93}$ Indeed, a majority of the Court in $R v$ Swain had already noted with concern that the mandatory detention being considered in that criminal law case was automatic in every situation "without any rational standard for determining which individual insanity acquittees should be detained and which should be released."94 Significantly, the Court in Swain reached this conclusion after rejecting government arguments that the legislation itself provided a sufficient trigger because the detention scheme applied by definition only to individuals convicted of certain criminal acts and acquitted due to insanity. While acknowledging that only particular individuals could be detained, a majority of the Court rejected this non-personalized approach, finding that the legislation was "still arbitrary in the way that it operates with respect to them [because] not all of these individuals will be dangerous." 95 It also warned that the lack of discretion inherent in mandatory detention will, in many cases, "render arbitrary the law's application." 96

Bills C-49, C-4, and C-31 mandate detention based on a group designation process that does not take into account the personalized circumstances or characteristics of particular

\footnotetext{
91 Ibid at para 89.

92 It is noteworthy that when the impugned Criminal Code provisions were subsequently revised, new language was also introduced. This eliminated the troubling term "insanity" and introduced the lexicon of "not criminally responsible for reasons of mental disorder (NCRMD)." Since the legal analysis in Swain refers to the former provisions, my discussion here adopts the associated terminology.

${ }^{93}$ Charkaoui, supra note 86 at para 89, citing $R$ v Swain, [1991] 1 SCR 993, 63 CCC (3d) 481 [Swain].

94 Ibid at para 130.

95 Ibid at para 131.

${ }^{96}$ Ibid at para 130, citing with approval, $R v$ Lyons, [1987] 2 SCR 309 at 348.
} 
detainees. If the Minister determines that a group is designated, ${ }^{97}$ any individual who arrives within that group and does not hold valid entry documentation (as is the case with the majority of asylum seekers) becomes a "designated foreign national" and is automatically detained for at least 12 months. Although it is obviously individual men, women, and children-each with their own histories and profiles-who will actually be subjected to this lengthy period of detention, the designation procedure is specifically designed to avoid an individualized process and instead attaches incredible consequences to a group label. This is particularly notable in Bills C-49 and 4, where even an individual's status as a young child was not deemed a relevant consideration. Further, the trigger for the group designation is itself vague and potentially completely benign: recall that one of the potential triggers is that the Minister simply believes that examinations of the group cannot be conducted in a timely manner. The result is a scheme which mandates detention with no assessment of the individual's personal circumstances; ${ }^{98}$ no determination of how feasible it might be to determine his or her identity or admissibility in a timely way; no investigation into his or her potential involvement with human smugglers, criminal organizations, or terrorist groups; no inquiry into the likelihood that a hearing date will be missed; and no evaluation to determine whether or not he or she poses a danger in any way. In short, there is no assessment to determine whether there are any rational grounds whatsoever to justify the detention.

The complete absence of a personalized detention trigger renders the scheme contained in the Human Smugglers Act directly analogous to the automatic detention provisions found to be unconstitutional in Swain. The need for a personalized assessment prior to detention was forcefully and recently reiterated by a unanimous Supreme Court in Charkaoui. There is thus leading and direct authority indicating that, subject to a potential justification under section 1,99 this aspect of the Human Smugglers Act constitutes a violation of the Charter. 2) The constitutional need for timely review of detention.

In Charkaoui, the court rejected a detention scheme that prohibited review for 120 days, finding that although some flexibility may be needed where a terrorist threat necessitates

\footnotetext{
${ }^{97}$ Recall that this can be done where the Minister is of the opinion that examinations and investigations of persons in the group cannot be conducted in a timely manner or that there are reasonable grounds to suspect either that a criminal or terrorist organization has benefited from assisting the group, or that the group has been assisted by an individual who has profited.

${ }^{98}$ A small exception may be available in rare cases, since the Minister is able to order release in "exceptional circumstances." See Bill C-49, supra note 1 at cl 13 (IRPA 58.1); Human Smugglers Act, supra note 4 at cl 14; Bill C31 , supra note 5 at $\mathrm{cl} 27$.

${ }^{99}$ Section 1 of the Canadian Charter provides the government an opportunity to justify prima facie violations of Charter rights. This aspect is discussed in more detail in "The inability to justify the prima facie Charter violations," below.
} 
immediate action, even that possibility could not "justify the complete denial of a timely detention review." 100 The court cited periods of 24 to 48 hours as guidance as to what might be considered "acceptable delays" before deprivations of liberty need to be reviewed, ${ }^{101}$ noting that permanent residents held under security certificates benefit from automatic review within 48 hours. Bills C- 49 , C-4, and C-31 introduced a mandatory detention scheme that is non-reviewable for 245 days more than the period that was rejected in Charkaoui, and in the absence of the compelling secrecy and security issues that complicate the security certificate context.

This latter point must be emphasized. The group designation process in the Human Smugglers Act means that individuals can be designated and detained without any evidence that they pose a threat to security or constitute a flight risk. This is in contrast to the situation in Charkaoui, where there was individualized evidence that each of the detainees represented a "threat to the security of Canada by reason of involvement in terrorist activities." 102 In that case, the 120 days of detention without review was found to violate the Charter's guarantee against arbitrary detention notwithstanding the severity of this risk. In its reasons, the Court emphasized that "whether through habeas corpus or statutory mechanisms, foreign nationals, like others, have a right to prompt review to ensure that their detention complies with the law."103 Application of this same principle to the Human Smugglers Act leads to the inevitable conclusion that the creation of a mandatory, 365-day unreviewable detention period ${ }^{104}$ for individuals against whom there is no evidence of a security concern is also a prima facie violation of Charter rights.

3) The constitutional need to respect principles of fundamental justice and avoid cruel and unusual treatment.

The Court in Charkaoui rejected arguments that extended periods of detention under the security certificate regime violated guarantees against cruel and unusual punishment and the right not to be deprived of liberty except in accordance with the principles of fundamental justice. ${ }^{105}$ This rejection was grounded in a finding that an assessment of personalized factors could justify the ongoing detention. In reaching this conclusion, the

\footnotetext{
${ }^{100}$ Charkaoui, supra note 86 at para 93.

101 Ibid at para 91.

102 Ibid at para 10.

103 Ibid at para 90.

${ }^{104}$ Note that the Human Smugglers Act permits (but does not require) release if the claim for refugee status is processed within the 365 days period of mandatory detention. At the time of writing, estimated average processing time for a refugee claim in Canada is $19-20$ months. See: Bill C-49, supra note 1 at cl 10 (amending IRPA s 56). See also Human Smugglers Act, supra note 4 at $\mathrm{cl} 11$; Bill C-31, supra note 5 at cl 32. The Canadian Bar Association maintains that release under such a provision would be unlikely. See Canadian Bar Association, "Bill C49, Preventing Human Smugglers from Abusing Canada's Immigration System Act" (November 2010), online: Canadian Bar Association <http://www.cba.org/cba/submissions/pdf/10-78-eng.pdf> at 5-6.

${ }^{105}$ These rights are protected by ss 12 and 7 of the Charter, respectively.
} 
court once again relied on the existence of a regular review process that took into account the circumstances of each individual detainee:

...the $s .7$ principles of fundamental justice and the $s .12$ guarantee of freedom from cruel and unusual treatment require that, where a person is detained or is subject to onerous conditions of release for an extended period under immigration law, the detention or the conditions must be accompanied by a meaningful process of ongoing review that takes into account the context and circumstances of the individual case. Such persons must have meaningful opportunities to challenge their continued detention or the conditions of their release. ${ }^{106}$

Given that the detentions authorized by the Human Smugglers Act are not premised on an assessment of the "context and circumstances of each individual" and are devoid of regular and ongoing review mechanisms, it seems most likely that its detention scheme is also in contravention of these additional Charter rights.

The inability to justify the prima facie Charter violations.

The Supreme Court of Canada in Charkaoui did not provide a robust explanation of why it found the prima facie Charter breaches relating to detention in the context of security certificates unjustifiable. Section 1 of the Charter allows the government to defend an apparent rights violation on the basis that it is justified in a free and democratic society. ${ }^{107}$ It is well established in Canadian law that a section 1 analysis requires consideration of a) the objective of the legislation; b) whether a rational connection exists between the objective and the impugned provisions; c) whether the claimant's rights have been minimally impaired; and d) whether the salutary benefits of allowing the violation outweigh the deleterious effects. ${ }^{108}$ Although a rigorous application of each phase of the section 1 framework (also called the "Oakes test," after the case in which it was established) was not offered in Charkaoui, the Court did conclude explicitly that even if a terrorist threat required immediate state action in the absence of a fully documented case, lack of a timely detention review would not be justified. The Court further held that the presence of a 48-hour review period for permanent residents subject to security certificates meant that the 120-day denial of review for foreign nationals could not be said

\footnotetext{
${ }^{106}$ Charkaoui, supra note 86 at para 107 [emphasis added].

${ }^{107}$ Section 1 of the Canadian Charter of Rights and Freedoms states: "The Canadian Charter of Rights and Freedoms guarantees the rights and freedoms set out in it subject only to such reasonable limits prescribed by law as can be demonstrably justified in a free and democratic society." Charter, supra note 3 at s 1.

${ }^{108}$ This well-established framework was originally provided by the Supreme Court of Canada in $R v$ Oakes, [1986] 1 SCR 103, 26 DLR (4th) 200.
} 
to constitute a "minimal impairment" of the protected rights, thus indicating that the scheme would fail the section 1 analysis on this basis. ${ }^{109}$

It must again be noted that the unreviewable detention period introduced by Bills C-49, C4, and C-31 is significantly longer than that considered in Charkaoui, while the competing security risks are far less concrete or imminent-if they are present at all. Further, it is significant that detainees in a direct comparator group-non-designated claimantsbenefit from review within 48 hours of detention. Just as the government was unable to justify offering timely review for some security certificate detainees and not others, there are no considerations that justify detention of designated foreign nationals seeking asylum for 182 times longer than non-designated asylum seekers.

Consideration of the section 1 analysis in Swain is also instructive on this point. In that case, six of seven judges found that the mandatory detention of individuals found to be insane at the time they committed a crime was unconstitutional and could not be saved by section 1 . The majority accepted that the impugned legislation had the pressing and substantial objective of protecting the public and preventing crime. It also concluded that there was a rational connection between this objective and the detention of all insanity acquittees since the impugned scheme would necessarily have the effect of ensuring that the individuals who posed a legitimate threat due to ongoing insanity were not released. The s. 1 justification failed, however, at the minimum impairment stage of the analysis. Here, a majority of the Court concluded that insanity acquittees should be detained "no longer than necessary to determine whether they are currently dangerous."110 Once again, the Court considered Parliament's use of more limited detention periods in other circumstances as evidence that the indeterminate detention imposed on these detainees was not minimally impairing of their Charter rights.

Applying this same reasoning to the potential justification of the detention schemes introduced by Bills C-49, C-4, and C-31, it is clear that even if the Human Smugglers Act is geared toward a pressing and substantial objective that is rationally connected to the mandatory detentions, ${ }^{111}$ detaining some asylum seekers for 365 days without review, and

\footnotetext{
${ }^{109}$ Charkaoui, supra note 86 at para 93: "It is clear that there may be a need for some flexibility regarding the period for which a suspected terrorist may be detained. Confronted with a terrorist threat, state officials may need to act immediately, in the absence of a fully documented case. It may take some time to verify and document the threat. Where state officials act expeditiously, the failure to meet an arbitrary target of a fixed number of hours should not mean the automatic release of the person, who may well be dangerous. However, this cannot justify the complete denial of a timely detention review. Permanent residents who pose a danger to national security are also meant to be removed expeditiously. If this objective can be pursued while providing permanent residents with a mandatory detention review within 48 hours, then how can a denial of review for foreign nationals for 120 days after the certificate is confirmed be considered a minimal impairment?" [Emphasis added].

110 Swain, supra note 93 at para 148.

${ }^{111}$ Although the Supreme Court of Canada has indicated that the rational connection analysis will not be overly rigorous, it is nonetheless arguable that justification of the Human Smugglers Act fails to meet this requirement.
} 
without linking their potential release to a finding that ongoing detention is necessary, cannot be justified because it does not constitute a minimum impairment of their rights. As with Swain and Charkaoui, this is even more obviously the case when other arrivals are guaranteed review of their detention within 48 hours.

It should again be noted that these concerns are even more acute in the detention regimes presented in Bills C-49 and C-4, where no allowance was made for designated foreign nationals who were children. Given previous precedent and common sense, it is inconceivable that a Canadian court would find the lengthy, unreviewable detention of a child justifiable in a situation where there is absolutely no evidence of a security threat or other potential harm.

Finally, it is also worth noting the observation of constitutional expert Peter Hogg that violations of the right not to be deprived of liberty except in accordance with principles of fundamental justice have never been successfully justified under section 1 , and the right to be free from cruel and unusual treatment may be an absolute right, immune from any form of justification. ${ }^{112}$ This means that if Bills C-49, C-4, and C-31 are in violation of these particular rights, it is even more unlikely that the breaches are justifiable.

In sum, Bills C-49, C-4, and C-31 introduced a detention regime that exacerbates features already found to violate the Canadian Charter in several significant ways. First, the mandatory detention is not triggered by an individualized assessment. Second, the length of time before the detention is reviewable is over three times as long as the period previously found to be unacceptable. And third, individuals can be detained without ongoing consideration of any personalized circumstances. Thus while some aspects of the Human Smugglers Act may raise novel constitutional concerns subject to multiple interpretations, the detention scheme does not. Rather, it directly contradicts recent and clear direction provided by the Supreme Court of Canada in the much more complicated context of security certificate detainees: the Human Smugglers Act reflects a far greater infringement of the relevant Charter rights with far less basis for justification than did the scheme that was successfully challenged in Charkaoui. This is thus not a situation

There is no data supporting the conclusion that mandatory detention will affect either the number of asylum seekers who seek refuge in Canada each year or the means through which they arrive. In addition, similar efforts in Australia were reversed after the government in that country acknowledged that "the evidence clearly shows [the measures] did not have any deterrent effect. In fact, there was an increase in the number of women and children making dangerous journeys to Australia." Australian Government, Department of Immigration and Citizenship, "Visas, Immigration, and Refugees", online: Department of Immigration and Citizenship <http://www.immi.gov.au/refugee/tpv_thv/abolition/overview.htm>.

112 Peter Hogg, Constitutional Law in Canada, 5th ed (Toronto: Carswell, 2010) at 38-49. 
highlighting complexities relating to the Charter's underdeterminacy-where application of judicial precedent involves reconciliation of competing authorities, or argument by analogy, or speculation about the reach of a particular principle. It is not even a situation where the balancing required by the justification analysis renders the outcome difficult to predict. Rather, the foregoing analysis demonstrates conclusively that the Human Smugglers Act is incapable of a credible and reasoned legal defence. It is therefore manifestly unconstitutional according to the Department of Justice's own definition of that term.

The political advantages of introducing manifestly unconstitutional legislation.

The Canadian government has not only actively pursued passage of the unconstitutional Human Smugglers Act, it has done so in an extremely public way. Two senior Ministers have spoken regularly on the proposed legislation, issued frequent press releases, written editorials, and toured the country to host special events. ${ }^{113}$ Further, the anti-human smuggling agenda formed a key part of the Conservative party's campaign strategy in Canada's 2011 federal election, and a variety of print and television advertisements featured images of the Sun Sea and warned against "bogus claimants", "illegal migrants", and the dire consequences of weak border security. ${ }^{114}$ The focus on fear and security is also evident in the Minister of Public Safety's heavy involvement in promoting the Human Smugglers Act - a presence that reinforces the notion that the bill is designed to deal with serious security threats and is necessary to ensure the safety of Canada.

The government's strategy to generate fear around asylum seekers, particularly those arriving by boat, is neither new nor without political merit. Similar "anti-boat people" rhetoric has featured prominently in the campaigns of many successful politicians, but was particularly noteworthy, and particularly successful, during Australia's "Tampa Affair." In 2001, thenAustralian Prime Minister John Howard used the maritime arrival of 438 Afghans to successfully brand asylum seekers arriving by boat as "illegal immigrants" who should not be allowed to set foot on Australian territory. The arrival of the Tampa, like that of the Sun Sea, generated intense media attention and precipitated (among other responses) the passage of a series of border protection bills; increased interdiction methods designed to keep "boat people" from ever reaching Australian waters; and an elaborate diplomatic arrangement whereby various South Pacific countries agreed to

\footnotetext{
113 Jason Kenney was the Minister of Immigration, Citizenship and Multiculturalism and Vic Toews was the Minister of Public Safety. The anti-human smuggling agenda features prominently on the websites of both ministries: Public Safety Canada, News Release, "Government of Canada takes action to prevent human smugglers from abusing Canada's immigration system" (16 June 2011), online: Public Safety Canada <http://www.publicsafety.gc.ca>; Citizenship and Immigration Canada, News Release, "Government of Canada takes action to prevent human smugglers from abusing Canada's immigration system" (16 June 2011), online: Citizenship and Immigration Canada <http://www.cic.gc.ca>.

${ }^{114}$ See for example: Conservative Election Ads at: "Human Smuggling" YouTube (March 2011), online: YouTube <http://www.youtube.com/watch?v=dmN8BpD09AQ>.
} 
accept and process asylum seekers in exchange for Australian aid money. ${ }^{115}$ The boat's arrival also became a major political issue and within days of the Tampa's arrival, Howard's Liberal party began running federal election ads very similar to those run by Harper's Conservative party in 2011. In Australia, Howard himself campaigned heavily on an immigration slogan in the wake of the Tampa's arrival: "We decide who comes into this country and the circumstances in which they come."116

Significantly, John Howard's hard line approach to the Tampa affair is viewed as a major political success: one week before the arrival of the boat, polls showed he was almost certainly going to lose the upcoming election; ${ }^{117}$ three months after its arrival he received a decisive renewed mandate. ${ }^{118}$ Many commentators point to the fact that $77 \%$ of Australians approved of his decision to turn away the Tampa as a major factor contributing to this stunning victory. ${ }^{119}$

Polling released shortly after the arrival of the Sun Sea indicates that many Canadians also favoured rejection of the boat, with $60 \%$ of those surveyed saying that the asylum seekers should be "turned away" and the vessel "escorted back to Sri Lanka."120 The Canadian

\footnotetext{
${ }^{115}$ For more on Australia's "Pacific Solution" see e.g.: Penelope Mathew, "Australian Refugee Protection in the Wake of the Tampa" (2002) 96:3 AJIL 661; Sarah Macdonald, “Australia's Pacific Solution" BBC News (26 September 2002), online: BBC News <http://news.bbc.co.uk>; United Nations High Commission for Refugees, "UNHCR welcomes close of Australia's Pacific Solution" (8 February 2008), online: UNHCR <http://www.unhcr.org>. The Australian High Court struck down the Pacific Solution on technical grounds in Plaintiff M70/2011 v Minister for Immigration and Citizenship, [2011] HCA 32. A recent expert report led by Angus Houston recommended that a comparable scheme be re-implemented. See: "Report of the Expert Panel on Asylum Seekers" (June 2012), online: < http://expertpanelonasylumseekers.dpmc.gov.au/report>.

${ }^{116}$ Lateline, "Liberals accused of trying to rewrite history", Australian Broadcasting Corporation (21 October 2001), online: Australian Broadcasting Corporation <http://www.abc.net.au/lateline/>.

${ }^{117}$ David Denemark, "Information flow and voter decision-making in the 2001 Australian federal election: The role of international and domestic issues", (Paper delivered at the Jubilee conference of the Australasian Political Studies Association, Australian National University, October 2002) [unpublished], online: Australian National University <http://arts.anu.edu.au/sss/apsa/Papers/denemark.pdf>.

118 John Howard's Liberal/ National Coalition won 82 seats in the House of Representatives (out of a total of 150), while the second place Labour Party won 65 seats. This represents an increase of two seats for the government and a decrease of two seats for the opposition, as compared to the pre-election seat distribution in the House of Representatives. See: Australian Electoral Commission, “Election 2001- House of Representatives: Divisions Won" (12 December 2001) online: Australian Electoral Commission <http://results.aec.gov.au>.

119 See e.g.: "Australia and refugees: Election ahoy" The Economist (6 September 2001) online: The Economist $<$ http://www.economist.com $>$. The attacks of September $11^{\text {th }}$ also aided the campaign of the Labour party and commentators note that Howard successfully linked the two issues, claiming that 9/11 confirmed the importance of the border security measures he had put in place as a result of the Tampa crisis.

${ }^{120}$ Brian Lilley, "Send Tamil migrants home: Poll" Toronto Sun (20 August 2010), online: Toronto Sun <http://www.torontosun.com>.
} 
government has used these figures to justify introduction of the Human Smugglers Act, saying that "something must be done because after the arrival of migrant vessels... Canadians are losing faith in the refugee system."121 Regardless of whether this is true, it is clear that the government views its "tough on smuggling" messaging as politically advantageous and thus worthy of loud publication. ${ }^{122}$

In this context, the caveat in Grant Huscroft's note 13 becomes important. Recall that there he anticipates that in certain situations, a government may be "indifferent to the constitutional fate of its legislation" because there will be sufficient political advantage to proceeding irrespective of Charter concerns. Further, Huscroft explains that in these circumstances, politicians will also be able to benefit from criticizing the court for interfering with popular legislation. ${ }^{123}$

I find Huscroft's theory to be directly relevant to the introduction of Bills C-49, C-4, and C31. Polls reporting a negative public reaction to the Sun Sea's arrival combined with the very public response to this incident before, during, and after the election campaign strongly suggest that the government sees this issue as one from which it can derive significant political traction. It may also be relevant that outside the context of the Human Smugglers Act, senior ministers within Canada's current government have publicly expressed both cynicism about the Charter's potentially constraining effects ${ }^{124}$ and concern

\footnotetext{
${ }^{121}$ Vic Toews, as cited in Sunny Dhillon, "Canadians 'hardening' on refugee process, Vic Toews says", The Globe and Mail (11 February 2011) online: The Globe and Mail <http://www.theglobeandmail.com>. Critics cited in the same article argue that government rhetoric about refugees must be blamed for any hardening of Canadian opinion on this subject.

${ }^{122}$ Some commentators have noted that the government appears to be using the introduction of the Human Smugglers Act as a "political wedge" aimed at creating divisive and harmful policy, see for example: Errol Mendes, "Human Smuggling Bill Just a Political Game", The Huffington Post Canada (28 September 2011) online: The Huffington Post Canada <http://www.huffingtonpost.ca>; Peter Showler, "Revenge of the Majority: Immigration and Refugee Policy in the Fall Parliament", Embassy Magazine (14 September 2011), online: University of Ottawa Human Rights Research and Education Centre <http://www.cdp-hrc.uottawa.ca/projects/refugeeforum/documents/RevengeoftheMajority.pdf>. Similar observations have been made with respect to John Howard's approach in Australia, and lan Ward's account of that situation represents a particularly interesting example. Ward argues that failure of the Australian media to recognize the Tampa incident as one of wedge politics ultimately aided Howard's divisive agenda, as the story was consistently covered as one dealing exclusively with "illegal immigrants" and border security. See: Ian Ward, "The Tampa, wedge politics, and a lesson for political journalism" (July 2002) 24(1) Australian Journalism Review 21.

${ }^{123}$ Huscroft, "Reconciling Duty", supra note 16 at note 13.

${ }^{124}$ Including in statements by the Minister of Citizenship and Immigration with regard to an announcement that women who wear face coverings will be required to remove them during citizenship ceremonies. When questioned about potential constitutional objections to the ban on the basis of freedom of religion, Minister Kenney stated: “I'm sure they'll trump up some stupid Charter of Rights challenge." Kim Mackrael and Les Perreaux, "Muslim Women Must Show Faces When Taking Citizenship Oath", The Globe and Mail (12 December 2011) online: The Globe and Mail <http://www.theglobeandmail.com>.
} 
about the legitimacy of courts reviewing legislation for constitutional compliance. ${ }^{125}$ The government is therefore already well positioned from an ideological perspective to critique a court that strikes down any of its politically popular legislation. Introduction of the Human Smugglers Act thus appears to map perfectly onto all of the factors in Huscroft's note 13 - a mapping which provides a persuasive explanation of why political considerations have failed to ensure that the government will not "introduce a bill that appears to be inconsistent with Charter case law."126

It is far more difficult to understand why introduction of the Human Smugglers Act did not yield a section 4.1 report. Section 4.1 promises to alert Canadians when the government is introducing legislation that is blatantly in violation of the Charter, and should be immune from the political considerations that might encourage a government to proceed even in the face of serious constitutional concerns. In fact, these situations are precisely those in which section 4.1 can and should play the most significant role, since a government's decision to proceed with legislation notwithstanding obvious Charter violations should be the subject of public scrutiny and debate. If even bills containing the most blatant constitutional deficiencies are insufficient to trigger a report, the accountability mechanism this process aims to provide has failed. Proof of this failure is unfortunately evident in the lack of a section 4.1 report accompanying Bill C-49, C-4, or C-31. As the following section explains, this failure to provide accountability does not mean that the reporting mechanism is not being put to use for other purposes.

\section{III) THE SHIFT FROM GOVERNMENT RESPONSIBILITY TO POLITICAL COVER.}

When the Human Smugglers Act was introduced, some commentators stated publicly that it was "inconceivable" that the senior politicians advancing its introduction were unaware of its blatant constitutional deficiencies. ${ }^{127}$ They criticized the government for manipulating the electorate through the deliberate introduction of unlawful legislation, alleging that doing so was an "affront to the rule of law" and an "insult to Canadians."128 Indeed, despite dozens of editorial and media pieces discussing the bill's lack of Charter compliance, not a

\footnotetext{
${ }^{125}$ Perhaps most famously, Prime Minister Stephen Harper has said that "Yes, I share many of the concerns of my colleagues and allies about biased 'judicial activism' and its extremes. I agree that serious flaws exist in the Charter of Rights and Freedoms, and that there is no meaningful review or accountability mechanisms for Supreme Court justices," as cited in Kirk Makin, "The coming conservative court: Harper to reshape judiciary", The Globe and Mail (13 May 2011) online: The Globe and Mail <http://www.theglobeandmail.com>.

${ }^{126}$ Huscroft, "Reconciling Duty", supra note 16 at 780.

${ }^{127}$ Audrey Macklin and Sean Rehaag, "Playing politics with refugees", Toronto Star (3 December 2010) online: Toronto Star <http://www.thestar.com>. ${ }^{128}$ Ibid.
} 
single expert has publicly defended the legislation's constitutional status. Even a prominent member of the Conservative party and supporter of many aspects of the proposals has noted that, "given precedent," it is "inconceivable that the Court would permit the automatic detention of smuggled migrants without review for a year."129 Many witnesses testifying before the House Standing Committee on Citizenship and Immigration during study of Bill C-31 expressed similar sentiments, and at least two individuals generally supportive of the bill testified that the detention provisions were "simply unconstitutional." 130 Nonetheless, both of the senior government ministers promoting the Human Smugglers Act continued to declare confidence in its constitutionality, with Minister Kenney stating repeatedly that the government is "absolutely certain that this meets our international and domestic legal obligations."131

Despite this unequivocal assertion, details underlying the government's legal position on the constitutionality of the Human Smugglers Act have never been made public, and government comments about Charter compliance are almost completely absent from the record. A review of statements by MPs before the committee considering Bill C-31, and in the House of Commons during debate on each of Bills C-49, C-4, and C-31 reveals a total of 9 government references to the Charter. None of these statements addresses Charkaoui or otherwise provides a substantive explanation of the grounds on which the government believes the Human Smugglers Act to be Charter compliant. ${ }^{132}$ This is in stark contrast with opposition statements, in which Charter concerns appear over 100 times, and frequently contain reference to specific provisions and alleged violations. The Charkaoui decision is also mentioned explicitly on multiple occasions, although demands that the government reconcile this case with the Human Smugglers Act go repeatedly unanswered, both in the House of Commons and in committee. ${ }^{133}$

\footnotetext{
${ }^{129}$ Benjamin Perrin, "Benjamin Perrin: A better plan to stop migrant smuggling”, National Post (14 November 2011) online: National Post <http://www.nationalpost.com>. Professor Perrin subsequently took a leave of absence to serve as special advisor to Prime Minister Harper on a variety of issues, including citizenship and immigration.

${ }^{130}$ See House of Commons Standing Committee on Citizenship and Immigration, 41st Parl, 1st Sess, Evidence No 37 (2 May 2012) at 1700 (Chantal Desloges); and House of Commons Standing Committee on Citizenship and Immigration, 41st Parl, 1st Sess, Evidence No 38 (3 May 2012) at 0900 (James Bissett).

${ }^{131}$ See e.g.: CTV.ca News Staff, "Smuggling bill would survive Charter challenge: Kenney", CTV.ca (24 October 2010), online: CTV.ca http://www.ctv.ca>. See also Vic Toews: "I am confident that the measures are Charter compliant", as reported in Meagan Fitzpatrick, "Human Smuggling Bill Makes a Return", CBC News (16 June 2011), online: CBC News <http://www.cbc.ca>.

132 House of Commons Debates on Bills C-49, C-4, and C-31 were searched, as was the evidence of the House of Commons Standing Committee on Citizenship and Immigration's study of Bill C-31. The number of government references to the Charter from all these sources totaled 9: 3 for each of C-49; C-4; and C-31.

${ }^{133}$ Results derived from electronic searches of the House of Commons Debates on Bills C-49, C-4, and C-31, as well as searches in the evidence of the House of Commons Standing Committee on Citizenship and Immigration's study of Bill C-31. The number of opposition party references to the Charter from all of these sources totaled 105: 12 for C-49; 63 for C-4; and 30 for C-31. Opposition members specifically mentioned the Charkaoui case on at least twelve distinct occasions during the Committee's study of the Bill.
} 
There are three notable exceptions to the government's general refusal to discuss the relationship between the Human Smugglers Act and the Charter as part of the legislative debate. Each of these is discussed briefly below.

First, on 27 March 2012, Minister Kenney appeared before the House of Commons Standing Committee on Citizenship and Immigration to discuss annual budget estimates. In response to a question by New Democrat MP Don Davies about the potential cost of defending the Human Smugglers Act in court, Minister Kenney reiterated that the government believed the legislation was Charter compliant. When pushed for further explanation in light of Charkaoui, he went on to explain that "[w]e believe there is a compelling policy objective in ensuring that we have identified illegal and irregular migrants....[that] there is a compelling security rationale for maintaining immigration detention for such individuals until we have identified who they are."134 This reference to a potential justification under section 1 of the Charter is obviously incomplete (and addresses only the first stage of the Oakes framework), but it is the most comprehensive explanation that has been provided by the government on the constitutionality of its proposals.

The second notable exchange regarding Charter compliance occurred during debates on Bill C-49, when Liberal MP Gerry Byrne asked to see the Department of Justice opinion finding the Human Smugglers Act consistent with the Charter:

Mr. Speaker, the government attempts to create fairness, and one of the great mediators of fairness is the Canadian Charter of Rights and Freedoms. Would the parliamentary secretary be prepared to table in the House an opinion by the Department of Justice as to whether or not all provisions within this bill will meet the test of the charter or a charter challenge?

Would he provide that to members of the House, so that we can review as to whether or not these provisions do indeed meet the test of fairness as prescribed by the Canadian Charter of Rights and Freedoms?135

The Parliamentary Secretary to the Minister of Public Safety responded as follows: Mr. Speaker, my colleague across the floor would know that I do not have such a document with me. Whether it exists or not, I do not know, but that is frequently an argument we hear from the opposite side, that it will not pass the test of the charter.

\footnotetext{
${ }^{134}$ House of Commons Standing Committee on Citizenship and Immigration, 41st Parl, 1st Sess, Evidence No 29 (27 March 2012) at 1650.

${ }^{135}$ House of Commons Debates, 40th Parl, 3rd Sess, No 39 (28 October 2010) at 1035 (Hon Gerry Byrne).
} 
We can always stand back and say it will not pass the test of the charter, and we will not know that until a court has ruled on it. However, as he knows from when his party was in power, the drafters of these bills come from within the legal branches of Justice and other branches. They have vetted it. They have brought it forward. This bill was not written on the back of a napkin or anything of that nature. It has been drafted properly, and I am sure my colleague is quite well aware of that. ${ }^{136}$

It is significant to note that this response allowed the government to rely on the authority associated with the Department of Justice's legal opinion, while simultaneously avoiding any meaningful discussion about the potential Charter inconsistencies in its proposed legislation. By declaring that the bill had been properly contemplated and vetted by experts, the government was able to both legitimize its position and shield itself from critiques on constitutional grounds without providing any details on the substance of its position.

A similar tactic was used in committee during consideration of Bill C-31. When asked directly by Liberal MP Kevin Lamoureux whether "the government is prepared to share any legal opinion with the committee membership that would suggest [the bill] is in compliance [with the Charter], or any legal opinion they have in regard to the mandatory detention issue," he was reminded by government MP David Tilson of earlier testimony by Department of Justice lawyer Scott Nesbitt, which indicated that "in fact the legislation is charter compliant [sic]."137 Review of the transcript, however, reveals that Mr. Nesbitt did not provide any specifics about the relevant Charter opinion, instead only vaguely referencing the government's belief that courts will consider both the "operational context" the government faces in situations of irregular arrivals and the "important objectives the bill is trying to achieve." He also referred to the fact that mandatory detention only follows designation, and that the latter is triggered in situations where it is "truly needed." When confronted with requests for more specific information about the constitutional status of the bill, including the applicability of Charkaoui, Mr. Nesbitt declined to provide further comment, instead reminding the committee that since section 4.1 requires an examination "of every government bill that's presented in the House to ensure it's consistent with the purposes and provisions of the charter...this bill wouldn't be before committee today had the Minister of Justice [found] ...that the bill was not consistent." He went on to explain that he was unable to provide details of the opinion on which this decision was based because "advice the department has provided is privileged."138

\footnotetext{
${ }^{136}$ Ibid at 1040 (Dave MacKenzie).

${ }^{137}$ House of Commons Standing Committee on Citizenship and Immigration, 41st Parl, 1st Sess, Evidence No 44 (10 May 2012) at 0950.

${ }^{138}$ House of Commons Standing Committee on Citizenship and Immigration, 41st Parl, 1st Sess, Evidence No 38 (3 May 2012) at $0935-0945$.
} 
Although Mr. Nesbitt was correct to note that as the government's lawyer he was precluded from disclosing details of advice given to his client, ${ }^{139}$ MP Kevin Lamoureux was likewise correct when he pointed out later in the day that the government, as client, could waive the solicitor-client privilege and provide the committee with the relevant legal documents, either in camera or in public. In response to Lamoreux's request that this occur, Conservative MP and Committee Chair David Tilson noted that such a thing had "never happened." He further doubted that "it ever will happen under my observation."140 Mr. Nesbitt's misleading assertion that government bills are vetted to ensure consistency with the Charter (as opposed to testing for "manifest unconstitutionality") was never re-visited or corrected.

This mischaracterization of the vetting threshold and the corresponding avoidance of substantive engagement with Charter issues are also evident in correspondence from Minister Kenney's office. The following exchange regarding the constitutionality of the Human Smugglers Act occurred between a journalist and Minister Kenney's press secretary:

\section{Kristen Shane, Associate Editor, Embassy Magazine:}

I'm writing a story...regarding the creation of a new group: the Canadian Association of Refugee Lawyers Executive members have told me that part of the impetus for starting the group was C-49/C-4, the Preventing Human Smuggling bill.

They say there are problems with it that make it unconstitutional. Primarily regarding the one-year automatic detention without judicial review. They say it violates Section 7 of the Charter, which says everyone has the right to life, liberty and security of the person.

...My questions for you: How do you respond to their claims that C-4 is unconstitutional? That the one-year detention without judicial review violates Section 7?...

Candice Malcolm, Minister Kenney's Press Secretary:

Kristen,

\footnotetext{
139 Ibid.

140 Ibid.
} 
Page 721 of the Second Edition of House of Commons Procedure and Practice O'Brien and Bosc states: "The Minister of Justice is required to examine every bill introduced by a Minister in order to ascertain that it is consistent with the Canadian Bill of Rights and the Canadian Charter of Rights and Freedoms."

Canada's immigration system is being abused by human smugglers who illegally bring migrants into Canada. Our government has received a strong mandate from Canadians to take action to prevent this abuse and maintain the integrity of our borders and Canadian citizenship. Canada opens its doors to those who work hard and play by the rules. However we must crack down on those who seek to take advantage of our generosity, often for financial gain.

Bill C-4 the Prevent Human Smugglers from Abusing Canada's Immigration System Act will work to deter and prevent human smugglers from targeting Canada. There are thousands of immigrants patiently waiting to start a better life in Canada; it is fundamentally unfair to legitimate refugees for human smuggling operations to jump the queue.

It is vital that Parliament pass this legislation, and we encourage the opposition to listen to Canadians and stop delaying the passing of this legislation.

Kind regards... ${ }^{141}$

While the initial inquiry from the journalist has been truncated here, the entire text from Minister Kenney's office is reproduced. Three familiar features of this exchange are particularly noteworthy: First, the reporter's question about a Charter violation arising from a particular aspect of the new legislation is answered with a direct reference to the section 4.1 reporting requirement. Second, the nature of the vetting process is once again significantly mis-characterized through reference to a finding of "consistency" with the Charter, rather than "inconsistency" or "manifest unconstitutionality." While this statement is an accurate quotation from the procedure manual mentioned, it is not at all reflective of the actual inquiry that is undertaken by government lawyers under section 4.1. ${ }^{142}$ And

\footnotetext{
${ }^{141}$ Email exchange on file with author. September $26-28,2011$.

${ }^{142}$ While the O'Brien and Bosc Procedural Manual refers to the need for verification of "consistency" with the Charter and the Bill of Rights, the Guide to Making Federal Acts and Regulations, to which O'Brien and Bosc refer, more accurately refers to a check for "inconsistency." Neither source refers to the "manifestly unconstitutional" threshold that is being applied. See respectively: O'Brien and Bosc, "Drafting Bills", House of Procedure and Practice, 2d ed (2009) online at: <http://www.parl.gc.ca/procedure-book-

livre/Document.aspx?Language=E\&Mode=1\&sbdid=DA2AC62F-BB39-4E5F-9F7D-

90BA3496D0A6\&sbpid=1E3A6719-B291-4B7D-B13B-52819E50CE14\#_ftn6>; and Guide to Making Federal Acts and Regulations, ch 2.4, online at: <http://www.pcobcp.gc.ca/index.asp?lang=eng\&page=information\&sub=publications\&doc=legislation/chap2.4-eng.htm>.
} 
third, while a number of points in favour of the Human Smugglers Act are raised, engagement with the substantive Charter issues that are mentioned in the journalist's initial email is completely absent.

The foregoing analysis suggests that while section 4.1 was introduced to promote government accountability in the face of Canada's human rights instruments, it is instead becoming a convenient form of political cover. When government representatives were faced with difficult constitutional critiques of the Human Smugglers Act, they used section 4.1 to invoke the legitimacy attached to review by Department of Justice lawyers while simultaneously avoiding any substantive engagement with Charter issues. Repeated misrepresentation of the threshold used during the section 4.1 vetting process further strengthened the impact of this technique. The result is a Canadian public that was both misled about the scrutiny to which Bills C-49, C-4, and C-31 were subjected and denied access to meaningful Charter debate. ${ }^{143}$ Thus rather than increasing accountability, section 4.1 contributed to a significant democratic deficit ${ }^{144}$ and decreased legitimacy. ${ }^{145}$

\section{IV) BEyond THE HUMAN SMUGGLER ACT}

Different bills; familiar techniques.

The Human Smugglers Act provides an important test for the effectiveness of the section 4.1 accountability mechanism because it so clearly runs contrary to recent and conclusive judicial precedent. The issues it demonstrates are not, however, anomalous. In November

\footnotetext{
${ }^{143}$ During a keynote address delivered at the Osgoode Hall Constitutional Conference on 4 May 2012, opposition MP and former Attorney General Irwin Cotler supported this interpretation of the government's use of s 4.1 to avoid meaningful debate. He added that the fact s 4.1 is limited to bills introduced by government also allows the entire review process to be circumvented through the use of private members bills. This latter point was also the subject of a media story which noted the government's support of a variety of private members bills that were being introduced by members of its own party: Tonda MacCharles, "Private member's bills cut corners on lawmaking, say critics", The Toronto Star (10 May 2012) online: The Toronto Star <http://www.thestar.com>. ${ }^{144}$ This term refers generally to "the gap between what Canadians expect of their political institutions in terms of democratic governance and what they perceive as reality," and has been used to describe a "wide range of current democratic discontents" (Peter Aucoin \& Lori Turnbull, "The Democratic Deficit: Paul Martin and Parliamentary Reform" (2003) 46:4 Can Pub Adm 427 at 436; 428). See also: Richard Devlin, A Wayne MacKay \& Natasha Kim, "Reducing the Democratic Deficit: Representation, Diversity and the Canadian Judiciary, or Towards a 'Triple P' Judiciary" (2000) 38:3 Alta L Rev 734; Katherine A Graham \& Susan D Phillips, "Citizen engagement: beyond the customer revolution" (1997) 40:2 Can Pub Adm 255; Patti Tamara Lenard \& Richard Simeon, eds, Imperfect Democracies: The Democratic Deficit in Canada and the United States, Vancouver, Toronto: UBC Press, 2012. ${ }^{145}$ Graham \& Phillips, supra note 144 at 255-56, have observed generally that "[m]any of the measures implemented over the past decade intended to enhance democracy, such as major public consultations and decentralization of policy responsibilities to increasingly local levels, have not produced the desired results. Indeed, in many cases, they have contributed to decreased legitimacy of political institutions."
} 
2009, a Globe and Mail article referred to the reporting requirement and noted that "cautious vetting is no longer the norm." 146 The article cites an anonymous source within the Department of Justice who states that the government's preoccupation with fulfilling certain policy objectives has made it willing to sign section 4.1 certificates "despite stern internal warning that [the attached bill] would likely violate Charter provisions." The source also notes that the reason for "barreling ahead" despite these warnings is perceived political advantage: "[t]hey made a lot of campaign promises that were either ill advised or not workable... [t] $]$ hen, when they came into power, they were hell-bent on making them happen." ${ }^{147}$ The Globe and Mail article containing these statements was written in response to several bills introducing controversial crime legislation, ${ }^{148}$ none of which triggered a section 4.1 report.

Referencing the reporting requirement to avoid meaningful constitutional debate can also be evidenced outside of the context of the Human Smugglers Act, and this practice was particularly pronounced during committee meetings relating to the Tackling Violent Crime Act. ${ }^{149}$ Like the Human Smugglers Act, the Tackling Violent Crime Act contained a number of controversial provisions that were subject to criticisms on both ideological and constitutional grounds. ${ }^{150}$ When the Minister of Justice appeared before the committee to support the bill, he informed committee members that his department "is very careful in terms of making sure that legislation, to the extent that we are able to predict these things, will withstand a challenge under the Charter of Rights and Freedoms." 151 He went on to explicitly invoke the legitimacy associated with review by the Department of Justice: So it's not just me; the people in the Department of Justice who are experts in this area take their responsibility very seriously. So yes, they draft every piece of legislation, every line, every clause, with a view to ensuring to the greatest extent possible that these will withstand constitutional challenge..$^{152}$

The Minister did not provide any details about why he or the Department of Justice had concluded that the legislation was "fully constitutional," instead reiterating only that he had "carefully considered" the Charter. ${ }^{153}$

\footnotetext{
${ }^{146}$ Kirk Makin, "Canadian Crime and American Punishment", The Globe and Mail (27 November 2009) online: The Globe and Mail <http://www.theglobeandmail.com>.

${ }^{147}$ Ibid.

${ }^{148}$ Ibid.

${ }^{149}$ Bill C-2, An Act to amend the Criminal Code and to make consequential amendments to other Acts, 2nd Sess, 39th Parl, 2007 (assented to 28 February 2008), SC 2008, c 6. This was an omnibus bill which included amendments to dangerous offenders legislation which were previously introduced (but not passed due to prorogation of the House) as Bill C-27, An Act to Amend the Criminal Code (Dangerous Offenders and Recognizance to Keep the Peace), 1st Sess, 39th Parl, 2007.

${ }^{150}$ But unlike the Human Smugglers Act, the alleged violations did not run directly contrary to recent and directly applicable authority from the Supreme Court of Canada.

${ }^{151}$ Legislative Committee on Bill C-2, 39th Parl, 2nd Sess (30 October 2007) at 1700 (Hon Rob Nicholson).

${ }^{152}$ Ibid.

${ }^{153}$ Ibid at 1645 (Hon Rob Nicholson).
} 
Despite these assurances, committee members were concerned when nine of twelve constitutional experts testified that the bill's reverse onus provision likely violated the Charter's guarantees of presumption of innocence. Opposition members began to demand more information regarding the government's Charter assessment and a motion was eventually tabled requesting that the Department of Justice provide the committee with all relevant legal opinions relating to the constitutionality of the bill "on a confidential, in camera basis which protects 'advice to the Minister.'"154

Speaking in support of the motion, Liberal MP Réal Ménard stated: Before voting on a bill, we have the responsibility of ensuring that we have all the information. Nine witnesses have told us this bill was not constitutional. I feel I am doing my job as a member of Parliament when I ask for information....

Why do we not have faith in the word of members of Parliament? [The motion says] that we would keep this information confidential. Is this not paid for with public funds? ... Is it unreasonable, as an elected official, to vote on a bill nine witnesses said was unconstitutional? Is it unreasonable to ask if this was investigated?

If the minister said so, that is not enough. We need more information ... I expect officials who have knowledge of constitutional law, who provided opinions to the minister, who are not from the private sector, who are paid with public funds, to give us that information. ${ }^{155}$

The government's parliamentary secretary responded to the concerns in two key ways: first, he reminded committee members that the minister had an obligation to certify bills only when "he believes the bills to be constitutional based on advice he receives" and that in this case the Minister felt the proposed legislation was "compliant with the Charter of Rights"; and second, he confirmed that advice received by the Minister on the issue of constitutionality is subject to solicitor-client privilege and thus cannot be provided. ${ }^{156}$

\footnotetext{
${ }^{154}$ The motion was tabled by Réal Ménard and subject to friendly amendment by Marlene Jennings. The amended motion read as follows: "That the Department of Justice be asked on a confidential, in-camera basis which protects 'advice to the Minister' to table all available legal opinions in its possession relating to the constitutionality of Bill C 2 by Friday, November 16, 2007, 3.00pm." See Legislative Committee on Bill C-2, "Minutes of Proceedings," 39th Parl, 2nd Sess (15 November 2007), online: Parliament of Canada $<$ http://www.parl.gc.ca>.

155 Ibid at 0915 (Réal Ménard).

${ }^{156}$ Ibid at 0905-0915 (Réal Ménard).
} 
When opposition members pointed out that the privilege could be waived, ${ }^{157} \mathrm{Mr}$. Moore stated simply that this "would not happen."158 The motion to require the Minister to produce more information on his Charter opinion was eventually defeated by one vote..$^{159}$

The widespread and systemic nature of the government's practices relating to the reporting requirement also became the subject of an extraordinary legal challenge while this article was awaiting publication. In December 2012, Department of Justice lawyer Edgar Schmidt began a proceeding in Federal Court seeking a declaration that the Department has not been fulfilling its reporting obligations under the Department of Justice Act and the Bill of Rights. According to Schmidt, "the interpretation, practice and directions [of the Department of Justice] ... have unlawfully transformed the examinations under the statutory examination provisions." 160 In particular, Schmidt contends that while the reporting requirements necessitate an examination focused on whether a proposed bill is consistent with Canada's human rights instruments, the examination actually undertaken by the Department of Justice is instead improperly "focused on the core question of whether there is any possibility (even if the possibility is very slender) that a proposed bill or regulation is consistent with the Bill of Rights and Charter." 161

Documents filed in relation to the Schmidt case reveal that the Department of Justice is currently assessing the risk associated with Charter compliance on a five-point scale, ranging from "very low" $(0-20 \%$ risk - likelihood of a successful challenge to the measure is "remote") to "very high" (81-100\% risk - likelihood of a successful challenge to the measure is "almost certain"). They also explain that the reporting requirement is only triggered "at the far end of the fifth range [very high] and is due to manifest inconsistency between the proposed legislation and the Charter. In such cases...no credible (ie. reasonable and bona fide) argument exists in support of it..."162 Schmidt's own statement of claim elaborates further on how this threshold is currently being applied:

...if it is the opinion of counsel in the Department that a provision is likely or even almost certainly inconsistent with the [Charter or Bill of Rights]-even if the probability of inconsistency is $95 \%$ or more-, but some argument can reasonably be made in favour of its consistency-even if all arguments in

\footnotetext{
157 Ibid at 0910-0915 (Hon Marlene Jennings).

158 Ibid at 0905-0910 (Rob Moore).

159 Ibid at 0925. Bill C-2 came into force in July 2008 and has since been the subject of numerous Charter challenges on a variety of grounds (see for example: $R v$ Powichrowski, 2009 ONCJ 490; $R v$ Fremlin, 2012 ONSC 888; $R$ v Nur, 2011 ONSC 4874; $R$ v Jaycox, 2010 BCPC 140; $R$ v MacAuley, 2010 BCPC 248; $R$ v Randhawa, 2010 Carswell Ont 10426). Of particular interest is $R v$ Jaycox, which was granted leave at the British Columbia Court of Appeal in February 2012 after the British Columbia Supreme Court reversed a Provincial Court finding that expanded police powers violated ss 8 and 10(b) of the Charter.

${ }^{160}$ Schmidt $v$ Canada (AG) (ongoing), Federal Court of Canada Court File No T-2225-12, Plaintiff Statement of Claim at para 18.

161 Ibid [emphasis added].

${ }^{162}$ Schmidt v Canada (AG) (ongoing), Federal Court of Canada Court File No T-2225-12, Documents produced by Defendant upon Motion, Appendix C, Extracts from Effective Communication of Legal Risk at pp $12-13$.
} 
favour of its consistency have a combined likelihood of success of 5\% or less-, no advice is given to the Minister that he or she- unless he or she forms a different opinion-has a duty to report to the House of Commons about that provision and therefore no report is made to that House. ${ }^{163}$

In March 2013, Justice Noël ordered the federal government to pay Schmidt's legal costs, noting that the proceeding raises issues that are "prima facie meritorious, of public importance and have not been resolved in previous cases." 164 At the time of writing, the merits of Schmidt's case have not yet been heard. ${ }^{165}$

Edgar Schmidt's stunning legal challenge thrust the issue of section 4.1 reporting into the public sphere ${ }^{166}$ and onto the floor of the House of Commons. On 6 March 2013, New Democratic Party (NDP) MP Pat Martin raised a question of privilege, claiming that if Schmidt's allegations about the vetting threshold are correct, the privilege of all MPs to be reassured that bills are not in violation of the Charter or the Bill of Rights has been breached. Martin stated that:

[the Department of Justice's failure in this regard] hinders us as members of Parliament in the performance of our parliamentary duties. It constitutes an interference in the performance of our duties to exercise due diligence of the bills before us. I believe every member of the House would agree that if these allegations are proven to be true, they show contempt for the authority and dignity of Parliament. 167

\footnotetext{
${ }^{163}$ Schmidt v Canada (AG) (ongoing), Federal Court of Canada Court File No T-2225-12, Plaintiff Statement of Claim at paras $13-14$.

${ }^{164} \mathrm{He}$ also noted that Mr. Schmidt has no personal benefit to gain from the proceeding: Schmidt v Canada (Attorney General), [2013] FCJ No 289 at paras 5 and 6.

${ }^{165}$ The day after launching his legal proceeding, Schmidt was suspended without pay "for violating his duties as a lawyer and public servant." At a hearing on 15 January 2013, Justice Noël criticized the suspension, calling it "unbelievable" and condemning the Department for doing "everything it could to kill [the legal proceeding]": Bill Curry, "Judge raps Justice officials for treatment of whistle-blower", The Globe and Mail (16 January 2013), online: The Globe and Mail <http://www.theglobeandmail.com/news/politics/judge-raps-justice-officials-fortreatmentof-whistle-blower/article7394559/\#dashboard/follows/>. Schmidt's employment issues have since been settled out of court and he is now retired from the federal public service: see Schmidt's website and blog, online at: http://charterdefence.ca/blog.html.

${ }^{166}$ See e.g. Kim Mackrael, "Justice Minister says 'no question' reforms will pass Charter test", The Globe and Mail (18 March 2013) online: The Globe and Mail < http://www.theglobeandmail.com/news/politics/justice-ministersays-no-question-reforms-will-pass-charter-test/article9868797/>; Laura Stone, "Government whistleblower just doing 'the right thing'", Global News (3 April 2013) online: Global News < http://globalnews.ca/news/453769/government-whistleblower-just-doing-the-right-thing/>.

${ }^{167}$ House of Commons Debates, 41st Parl, 1st Sess, No 220 (6 March 2013) at 1710, online: Parl.gc.ca <http://www.parl.gc.ca/HousePublications/Publication.aspx?
} 
The Speaker of the House declined to comment on the adequacy of the government's approach to the vetting process, however, finding that questions of a legal or constitutional nature are beyond the scope of his mandate. ${ }^{168}$

The issue was raised again on 17 June 2013 when Liberal MP Irwin Cotler introduced Bill C-537: the Constitutional Compliance Review Act. ${ }^{169}$ The bill proposed giving the Law Clerk and Parliamentary Counsel of the House of Commons and Senate responsibility for vetting all proposed legislation for constitutional compliance. It further specified that a report should be submitted when it is deemed "likely" that any of a bill's provisions are inconsistent with the purposes or provisions of the Bill of Rights or the Constitution Acts, 1867 to $1982 .{ }^{170}$ Bill C-537 died on the order paper when Parliament was prorogued in September 2013. Details of the section 4.1 reporting requirement therefore remain unchanged.

\section{The need to recognize failure}

As our detailed study of the Human Smugglers Act has demonstrated, section 4.1 of the Department of Justice Act is not only failing its mandate to provide accountability through reports of inconsistency, it is also providing the government with political cover when it wishes to avoid substantive critique on Charter grounds. The ultimate result is not only a lack of report in situations of egregious Charter violation, but also impoverished constitutional debate and a significant democratic deficit.

The remedy for this is not, however, to simply repeal section 4.1 of the Department of Justice Act and forget about the reporting requirement in its entirety. Despite recent comments that the government is prepared to knowingly "barrel ahead" with unconstitutional legislation, the vetting process ensures that the human rights implications of new legislation are at least considered before a government bill is introduced. Further, the internal correction model very likely ensures that at least some Charter concernsparticularly those that are neither deliberate nor necessary to fulfill a particular government policy-continue to be remedied prior to tabling in the House of Commons. The reporting aspect of the process incentivizes identifying and correcting these errors before the bills are subjected to public scrutiny.

\footnotetext{
Language $=E \& M o d e=1 \&$ Parl $=41 \&$ Ses $=1 \&$ Docld $=6027810 \# S O B Q-7922406>$.

${ }^{168}$ House of Commons Debates, 41st Parl, 1st Sess, No 230 (27 March 2013) at 1600-

1620, online: Parl.gc.ca <http://parl.gc.ca/HousePublications/Publication.aspx?

Language $=\mathrm{E} \& M$ ode $=1 \& \mathrm{Parl}=41 \&$ Ses $=1 \&$ Docld $=6069821 \#$ SOB-7952682 $>$.

${ }^{169}$ Bill C-537, Constitutional Compliance Review Act, 41st Parl, 1st Sess, 2013 (first reading 13 June 2013).

170 Ibid at $\mathrm{cl} 6(2)$.
} 
The potential value of an effective reporting requirement is also evidenced elsewhere, where public reports on the human rights consequences of legislation encourage, rather than stifle, meaningful public debate. Both the United Kingdom (UK) and New Zealand, for example, have processes through which proposed legislation is subjected to genuine scrutiny for human rights concerns, with results being made available not only to politicians debating the proposals, but also the general public. ${ }^{171}$ In the UK, this assessment is performed by the Joint Committee on Human Rights (a Parliamentary Committee), which considers government and private Members' bills for their human rights implications. The Chairman and Legal Advisor consider all bills and report those that seem to have significant human rights implications to the committee as a whole, which then undertakes more focused scrutiny. Private members bills are only considered where they both raise significant human rights issues and appear likely to become law. ${ }^{172}$ In New Zealand, legislative scrutiny is performed by the Ministry of Justice and the Crown Law Office. The Attorney General is required to notify the House of Representatives of any government bill that is deemed to be inconsistent with the New Zealand Bill of Rights at the time of its introduction. In the case of private Members' bills, the report must be made as soon as is practicable. ${ }^{173}$ The process of publicizing legal opinions is more discretionary in the United States, but the Attorney General's Office of Legal Counsel (OLC) "operates from the presumption that it should make its significant opinions - including those dealing with the constitutional compliance of proposed legislation - fully and promptly available to the public" in order to encourage "transparency", "accountability" and "public confidence in the legality of government action."174 The OLC has also published details about how its legal opinions are prepared and what factors are relevant to a decision not to disclose. ${ }^{175}$ Although the processes in these countries vary significantly, all have resulted in the identification of numerous issues of concern that were subsequently considered and openly debated as part of the legislative process. ${ }^{176}$

\footnotetext{
${ }^{171}$ For interesting comparative work, especially between Canada and New Zealand, see Janet L. Hiebert, "Parliamentary Bills of Rights: An Alternative Model" (2006) 69:1 MLR 7 [Hiebert, "Parliamentary Bills of Rights"]; Hiebert, "Rights-Vetting", supra note 16; Huscroft, "Reconciling Duty", supra note 16.

${ }^{172}$ UK, House of Lords and House of Commons, Joint Committee on Human Rights, "The Committee's Future Working Practices: Twenty-third Report of Session 2005-06" (4 August 2006) 12, online: Parliament of the United Kingdom <http://www.publications.parliament.uk/pa/jt200506/jtselect/jtrights/239/239.pdf>.

${ }^{173}$ New Zealand Ministry of Justice, "Section 7 of the New Zealand Bill of Rights Act", online: New Zealand Ministry of Justice <http://www.justice.govt.nz>.

${ }^{174}$ US, Department of Justice, Office of Legal Counsel "Memorandum for Attorneys of the Office: Best Practices for OLC Legal Advice and Written Opinion", (Washington, DC, 16 July 2010) online at: <http://www.justice.gov/olc/pdf/olc-legal-advice-opinions.pdf> at 5.

${ }^{175}$ Ibid.

${ }^{176}$ Reports issued by the Joint Select Committee on Human Rights of the Parliament of the United Kingdom can be found online at <http://www.parliament.uk/business/committees/committees-a-z/joint-select/human-rights-
} 
A variety of proposals for reform have been made in the Canadian context. Commentators have suggested separating the offices of the Attorney General (AG) and the Minister of Justice (and making the AG responsible for government litigation and constitutional advice, while the Minister of Justice would be responsible for legal policy); 177 giving greater independence to the Minister of Justice, such that the role assumes a more non-partisan character; ${ }^{178}$ giving the Minister sponsoring the bill's introduction responsibility for providing any justification analysis under section 1; ${ }^{179}$ establishing review by a parliamentary committee, similar to that in the UK; ${ }^{180}$ changing the reporting threshold to "serious probability" or something else less than the near certainty implied by the standard of "manifest unconstitutionality"; ${ }^{181}$ making public the policy manuals which establish the vetting process and threshold; ${ }^{182}$ and requiring production of a statement of compatibility or incompatibility, including an associated assessment, for every bill.183 It has been further suggested that the reporting requirement should be extended to private members bills; ${ }^{184}$ that all reports should be made public; 185 and that a report should be accompanied by a waiver of solicitor-client privilege for the underlying opinion as well as use of the notwithstanding clause if the government chooses to proceed. ${ }^{186}$ I would add to this list

committee/Publications/>. Reports issued by the New Zealand Ministry of Justice are published online at <http://www.justice.govt.nz/policy/constitutional-law-and-human-rights/human-rights/domestic-human-rightsprotection/about-the-new-zealand-bill-of-rights-act/advising-the-attorney-general/section-7-reports-publishedbefore-august-2002/section-7-reports-published-before-august-2002>. In addition, since 2003, the government of New Zealand has voluntarily made the advice provided to its Attorney-General available on the Ministry of Justice website (Andrew Geddis, "The Comparative Irrelevance of the NZBORA to Legislative Practice" (2009) 23 NZULR 465 at 474; Carolyn Archer, "Section 7 of the Bill of Rights Act" [2004] NZLJ 320 at 320). Opinions of the United States Attorney General on questions of law rendered upon request of the President or the head of an Executive Branch department are officially released and published online at <http://www.justice.gov/olc/memorandaopinions.html>. Those opinions that have not been selected for official release, but which the OLC has released as a matter of discretion, are published online at <http://www.justice.gov/olc/olc-foia1.htm>. While approaches across these countries vary, it is noteworthy that they are all considerably more open than that in place in Canada, where Charter opinions are not provided (to either the public or MPs) under any circumstances.

177 James B Kelly and Matthew A Hennigar, "The Canadian Charter of Rights and the minister of justice: Weak-form review within a constitutional Charter of Rights" (2012) 10 I.Con 35 [Kelly and Hennigar].

${ }^{178}$ Roach, "Not Just the Government's Lawyer", supra note 38.

${ }^{179}$ Kelly and Hennigar, supra note 176.

${ }^{180}$ Hiebert, "Parliamentary Bills of Rights", supra note 171 at 15.

${ }^{181}$ Roach, "Not Just the Government's Lawyer", supra note 38.

182 Dodek, supra note 32.

${ }^{183}$ Kelly and Hennigar, supra note 176.

${ }^{184}$ Roach, "Not Just the Government's Lawyer", supra note 38; Kelly, "Legislative Activism”, supra note 37 at 86. 185 Ibid.

${ }^{186}$ Roach, "Not Just the Government's Lawyer", supra note 38. Section 33 of the Canadian Charter allows a government to pass legislation "notwithstanding" the fact it violates one of the instrument's substantive guarantees. A similar recommendation has been made in the New Zealand context by Archer, supra note 176:

"There is clearly a public interest in the protection provided to communications between lawyers and their clients, but in the case where the Attorney-General presents a s 7 report to the government, the greater public interest is 
the possibilities of making reports which include substantive discussion of Charter concerns available to parliamentarians, but not the public, and a potentially more robust role for the lawyers housed within Parliament, either in the offices of the Law Clerk and Parliamentary Counsel for the House of Commons and Senate or in the Library of Parliament. 187

There are undoubtedly other possible models worthy of exploration. The first step, however, must be recognition that the current system has failed. The analysis in this contribution attempts to demonstrate the inevitability of this conclusion: while the significance of the lack of section 4.1 reports can be debated in the abstract, the absence of a notice of non-compliance when the Human Smugglers Act was introduced is indicative of a process that is failing to provide accountability. Further, this process is failing in the moments it is most needed: when the government chooses to introduce legislation for political benefit, notwithstanding the constitutional risks associated with doing so. We must recognize this failure and turn our collective minds to a remedy.

In the interim, we must also clarify the public record with respect to the nature of the section 4.1 vetting process so that it ceases to serve as a convenient form of political cover. The threshold on which bills are assessed should be overtly clarified and insisted upon so that the public is less easily misled by claims that review by government lawyers negates all Charter concerns. And we should all recall that internal vetting for bills that are manifestly unconstitutional is not a substitute for genuine and public constitutional debate. Even less so when the threshold being applied in that analysis fails to identify even the most egregious of violations, such as those that were introduced not once but three times in the form of the Human Smugglers Act.

\footnotetext{
to be found in fostering open government and a transparent legislative process. Thus privilege protection should be overridden in this context."

187 The Law Clerk and Parliamentary Counsel, who reports to the Clerk of the House of Commons, provides legal counsel services to the Speaker of the House, the Board of Internal Economy, Members of the House of Commons, the Clerk, and other officials of the House of Commons' administration. Additionally, the Law Clerk and Parliamentary Counsel provides legal and legislative counsel services to members and to House committees. See Canada, Board of Internal Economy, Governance and Administration By-Law at s 11, online: Parliament of Canada <http://www.parl.gc.ca/About/House/BOIE/boie-ByLaw-AdministrationB-e.html>.

The Law Clerk and Parliamentary Counsel to the Senate provides similar services in the Upper House. The Library of Parliament also provides research and analysis services to parliamentarians and their staff on a variety of topics, including legal issues. For some examples of Library of Parliament publications, see <http://www.parl.gc.ca/About/Library/VirtualLibrary/ResearchPublicationsCurrent-e.asp>.
} 